Article

\title{
Hydrogen Oxidation on Ni-Based Electrocatalysts: The Effect of Metal Doping
}

\author{
Elena S. Davydova ${ }^{1,2, *}$, Jérémie Zaffran ${ }^{2,3}$, Kapil Dhaka ${ }^{3}$, Maytal Caspary Toroker ${ }^{2,3, *}$ and \\ Dario R. Dekel 1,2,*(D) \\ 1 The Wolfson Chemical Engineering Department, Technion-Israel Institute of Technology, \\ 3200003 Haifa, Israel \\ 2 The Nancy and Stephen Grand Technion Energy Program (GTEP), Technion-Israel Institute of Technology, \\ 3200003 Haifa, Israel; zaffran.j@gmail.com \\ 3 Department of Material Science and Engineering, Technion-Israel Institute of Technology, \\ 3200003 Haifa, Israel; kapil87dhaka@gmail.com \\ * Correspondence: elena.s.davydova@gmail.com (E.S.D.); maytalc@technion.ac.il (M.C.T.); \\ dario@technion.ac.il (D.R.D.); Tel.: +972-54-9958377 (E.S.D.)
}

Received: 27 September 2018; Accepted: 11 October 2018; Published: 15 October 2018

check for updates

\begin{abstract}
Carbon supported nanoparticles of monometallic Ni catalyst and binary Ni-Transition Metal (Ni-TM/C) electrocatalytic composites were synthesized via the chemical reduction method, where TM stands for the doping elements $\mathrm{Fe}, \mathrm{Co}$, and $\mathrm{Cu}$. The chemical composition, structure and morphology of the Ni-TM/C materials were characterized by X-ray photoelectron spectroscopy (XPS), $X$-ray diffraction (XRD), transmission electron microscopy (TEM), scanning transmission electron microscopy (STEM) and energy-dispersive X-ray spectroscopy (EDS). The electrochemical properties towards hydrogen oxidation reaction in alkaline medium were studied using the rotating disc electrode and cycling voltammetry methods. A significant role of the TM dopants in the promotion of the hydrogen electrooxidation kinetics of the binary Ni-TM/C materials was revealed. A record-high in exchange current density value of $0.060 \mathrm{~mA} \mathrm{~cm}{ }^{2} \mathrm{Ni}$ was measured for $\mathrm{Ni}_{3} \mathrm{Fe}_{1} / \mathrm{C}$, whereas the monometallic $\mathrm{Ni} / \mathrm{C}$ counterpart has only shown $0.039 \mathrm{~mA} \mathrm{~cm}^{2} \mathrm{Ni}$. In order to predict the feasibility of the electrocatalysts for hydrogen chemisorption, density functional theory was applied to calculate the hydrogen binding energy and hydroxide binding energy values for bare $\mathrm{Ni}$ and $\mathrm{Ni}_{3} \mathrm{TM}_{1}$.
\end{abstract}

Keywords: metal doping; nickel-based catalyst; transition metals; synthesis; hydrogen oxidation reaction; exchange current density; alkaline medium; DFT; hydrogen binding energy; hydroxide binding energy

\section{Introduction}

Anion exchange membrane fuel cells (AEMFCs) have seen a rapid increase in interest in recent years [1,2], as they promise to overcome the existing cost barriers inherent to low temperature acidic polymer electrolyte membrane fuel cells. In the past 3 years, extensive research in AEMFCs, mainly in polymer performance stability [3-12], carbonation effects [13-15] and modelling [16-19], led to significant progress in this technology. However, in spite of this progress, in order to fulfill the optimistic potential of AEMFCs in the near future, catalysts should be completely free of expensive noble metals, and eventually free of critical raw materials. Although great progress has been done in the development of Pt-free catalysts for oxygen reduction reaction in base medium [20,21], significantly less attention has been paid to the catalysis for the hydrogen oxidation reaction (HOR). The lack of fundamental understanding of the HOR mechanism in basic media and of the main energy barriers needs to be firmly established to overcome this challenge. In a recent comprehensive study, challenges 
of HOR catalysis in alkaline electrolytes were reviewed [22]. The review presents the most updated understanding of the HOR electrocatalysis in basic media and outlines promising future research directions for the development of better HOR electrocatalysts for alkaline electrolytes, mainly to be used for advanced AEMFC devices.

High-performance AEMFCs have been recently reported, showing peak power values that well exceed $1.0 \mathrm{~W} \mathrm{~cm}{ }^{-2}$; predicting performance stability in anion exchange membrane fuel cells $[7,23]$ however, all of these state-of-the-art AEMFCs exclusively rely on Pt-based HOR catalysts [24]. Very few studies reporting AEMFC performance with zero-platinum loading can be found [24]. Among them, the highest performing Pt-free AEMFCs consist of palladium-based catalysts for the HOR, showing performance close to that of platinum, with peak power densities of $0.4-1.4 \mathrm{~W} \mathrm{~cm}^{-2}$ [25-27]. However, complete removal of platinum group metals (PGMs) in AEMFC anodes is still widely recognized as a major challenge [22,24].

Nickel exhibits the most promising HOR activity of any of the 3d transition metals (TM) [22]. However, until now, undoped Ni electrocatalysts demonstrate about two orders of magnitude lower activity than Pt or Pd [22]. Calculations predicted that doping of $\mathrm{Ni}$ by TMs decreases Ni-H bond strength $[28,29]$, thus, allowing to optimize hydrogen binding energy (HBE) values via positively shifting them close to those of PGMs [30]. Nickel doping was also reported to suppress nickel oxophilicity, and hence, to impede surface (electro)oxidation [31]. It was reported that alloying $\mathrm{Ni}$ with other $3 \mathrm{~d}$ TM helps to prevent the formation of Ni-hydride and increases the durability of the electrodes in hydrogen evolution reaction (HER) $[32,33]$, strengthening the understanding that $\mathrm{Ni}$ doping is a powerful tool in modifying and tailoring $\mathrm{Ni}$ (electro)catalytic properties.

Several studies have examined the doping effect of TM for some binary [29,34-38] and ternary [29] Ni-based alloys for HOR in base media. Sheng et al. [29] showed that ternary metallic CoNiMo layers electrodeposited on the surface of Au substrate exhibit a significant increase of exchange current density $\left(0.015 \mathrm{~mA} \mathrm{~cm}^{-2}\right)$, as compared to bulk Ni $\left(0.002 \mathrm{~mA} \mathrm{~cm}^{-2}\right)$. The authors suggested that the formation of multi-metallic bonds modified the $\mathrm{HBE}$ value of $\mathrm{Ni}$ and likely contributed to the enhanced HOR activity [29]. However, thick layers of the electrodeposited CoNiMo layers might be of low

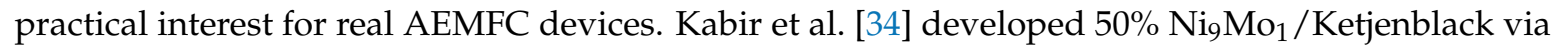
thermal reduction method under $\mathrm{H}_{2}$ flow at $550{ }^{\circ} \mathrm{C}$, with oxidative treatment in $2 \% \mathrm{O}_{2} / \mathrm{He}$ mixture for $8 \mathrm{~h}$ at room temperature. The resultant $\mathrm{Ni}$-Mo catalyst was shown to comprise only ca. $2 \% \mathrm{NiMo}_{4}$ alloy, however the authors assumed that the enhanced activity of Ni-Mo catalyst could be ascribed to the decrease in $\mathrm{HBE}$ value by ca. $0.14 \mathrm{eV}$, as compared to that of unmodified Ni. The authors showed that an AEMFC based on this Ni-Mo/C anode catalyst and Pd/C cathode catalyst, can reach a peak power density value of $0.12 \mathrm{~W} \mathrm{~cm}^{-2}$ [34].

In another study, binary Ni-Ag bulk alloys across a range of compositions were deposited on glassy carbon substrate using electron beam evaporation [36]. X-ray diffraction (XRD) data showed that e-beam evaporation results only in partial alloying of $\mathrm{Ni}$ and $\mathrm{Ag}$, while the rotating disk electrode (RDE) measurements revealed a negligible effect of silver doping on the catalytic activity of $\mathrm{Ni}$ towards hydrogen electrooxidation. Zhuang et al. [28] showed that by developing nickel nanoparticles supported on nitrogen-doped carbon nanotubes (CNTs) via hydrothermal treatment at $150{ }^{\circ} \mathrm{C}$ in the presence of ammonia and hydrazine, the catalytic activity of bare $\mathrm{Ni}$ can be significantly improved ( 0.028 for Ni/N-CNT vs. $0.0014 \mathrm{~mA} \mathrm{~cm}^{-2}{ }_{\mathrm{Ni}}$ for bare $\mathrm{Ni}$ in $0.1 \mathrm{M} \mathrm{KOH}$ ). The authors attributed the promoted HOR activity to the synergetic effect of the optimal HBE resulting both from geometric and electronic interaction of Ni atoms with the edge $\mathrm{N}$ atoms in CNT. Although the authors achieved a high mass activity (ca. $9 \mathrm{~A} \mathrm{~g}_{\mathrm{cat}^{-1}}{ }^{-1}$ ), the elegant but still single data point does not anticipate the future directions for improving the catalytic activity of Ni. Cherstiouk et al. [37] have proposed a series of $\mathrm{Ni}_{x} \mathrm{Cu}_{1-\mathrm{x}} /$ Vulcan XC72 electrocatalysts obtained via successive wet impregnation, calcination and reduction in $\mathrm{H}_{2}$ at $250{ }^{\circ} \mathrm{C}$ for $1 \mathrm{~h}$. The authors assume that the enlargement of the lattice parameter for $\mathrm{Ni}_{9.5} \mathrm{Cu}_{0.5} /$ Vulcan XC72 suggests the formation of $\mathrm{Ni}-\mathrm{Cu}$ alloy with ca. 5 at.\% $\mathrm{Cu}$ content. The enhancement of the HOR activity of Ni-Cu samples $\left(0.014 \mathrm{~mA} \mathrm{~cm}^{-2}\right)$ compared to $\mathrm{Ni}$ 
$\left(0.004 \mathrm{~mA} \mathrm{~cm}^{-2}\right)$ was tentatively explained by the electronic effect of $\mathrm{Cu}$ resulting in the decrease of the energy of adsorption of the hydrogen intermediate.

In summary, certain moderate progress was done in understanding the role of the TM dopant nature and doping level on the catalytic properties of Ni towards HOR in alkaline. However, there is still an enormous gap between systematic understanding of the dopant role in the HOR electrocatalysis and the random results of the experimental data.

In this work, we undertake a systematic scanning of the first row TMs, from Sc to Zn, to predict by density functional theory (DFT) calculations the HBE and OH binding energy (OHBE) values for three different facets—(111), (200) and (220)—of bimetallic face-centered cubic (FCC) $\mathrm{Ni}_{3} \mathrm{TM}_{1}$ alloys. To reveal the effect of TM doping on the electrocatalytic properties of nanosized $\mathrm{Ni}_{3} \mathrm{TM}_{1}$ electrocatalysts, the HOR kinetics of monometallic $\mathrm{Ni} / \mathrm{C}$ and bimetallic $\mathrm{Ni}_{3} \mathrm{TM}_{1} / \mathrm{C}$ composites in $1 \mathrm{M} \mathrm{KOH}$ was also systematically measured for selected TMs that were found to be potentially interesting based on the DFT calculations.

\section{Results and Discussion}

\subsection{Theoretical Prediction}

DFT method was used to calculate the HBE and OHBE values on (111), (200), and (220) facets of $\mathrm{Ni}_{3} \mathrm{TM}_{1}$ alloys. The HBE and OHBE values are presented in Tables A1-A6 (Appendix A). To the best of our knowledge, this is the first time the OHBE values were calculated for the electrocatalysts. Figure 1 shows the calculated HBE values (Figure 1a) and OHBE values (Figure 1b) for the case of pure $\mathrm{Ni}$ and different $\mathrm{Ni}_{3} \mathrm{TM}_{1}$ alloys. As seen in Figure 1 and Tables A1-A3 (Appendix A), hydrogen atom has the lowest HBE for the (111) facet, compared to the (220) and (200) facets. For example, HBE value for bare $\mathrm{Ni}(111)$ is $-0.54 \mathrm{eV}$, while is -0.48 and $-0.45 \mathrm{eV}$ for $\mathrm{Ni}$ (200) and $\mathrm{Ni}(220)$, respectively (see also Tables S1-S3, Supplementary Materials). The reason for the stability of the (111) facet is that $\mathrm{H}$ atoms can establish more bonds on the (111) facet, which is more atomically dense than other facets. The facet $\mathrm{Ni}(200)$ of the bare $\mathrm{Ni}$ shows the highest affinity to $\mathrm{OH}$ chemisorption and the facet (220) is characterized by the weakest OH bonding (OHBE: $(200) \ll(111)<(220))$ (Figure $1 b$ ). The comparison of OHBE and HBE values (HBE and OHBE are $-0.54 \mathrm{eV}$ for (111), and HBE is -0.45 and $\mathrm{OHBE}$ is $-0.49 \mathrm{eV}$ for (220)) shows that the co-adsorption of the both $\mathrm{H}$ and $\mathrm{OH}$ species is thermodynamically favorable.
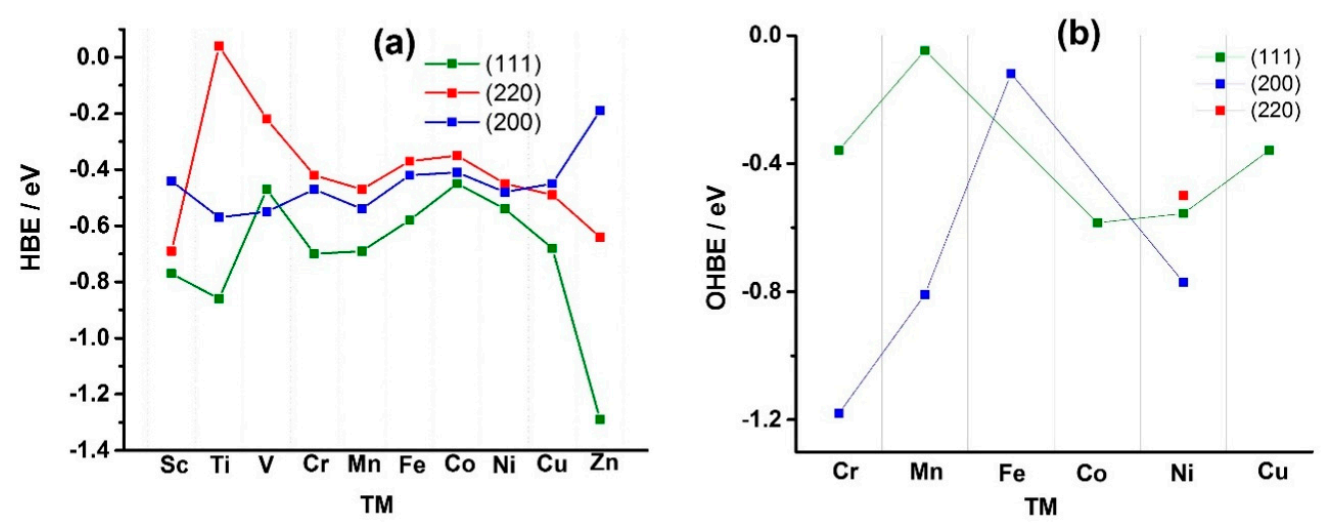

Figure 1. HBE (a) and OHBE (b) values on different facets for $\mathrm{Ni}_{3} \mathrm{TM}_{1}$ alloys presented in the same order as the $3 \mathrm{~d}$ TMs in the Periodic Table.

Some authors assume that the kinetics of HOR directly follows the thermodynamics of the reaction $[39,40]$, and therefore it is explicitly related to the HBE values according to the so-called volcano plot [41], where HOR/HER exchange current densities are plotted versus HBE, with the PGMs normally at the top of the graph. The optimal HBE value was predicted to be ca. $-0.24 \mathrm{eV}$, which corresponds to the HOR $\Delta \mathrm{G} \sim 0$ [41]. HBE might be considered as the main factor influencing the HOR 
kinetics solely in case the rate-determining step (rds) of the reaction is either Volmer [42], or Heyrovsky reactions [43], namely the removal of the adsorbed $\mathrm{H}$ atom from the catalyst surface. Studies of the HOR mechanism in alkaline for Pt electrocatalysts have revealed a controversy in the experimental data interpretation [22]: while some of the authors experimentally proved that Tafel reaction is the HOR rds [44-48], others provided experimental evidence for the HOR kinetics limited by the Volmer reaction $[49,50]$.

The mechanism of HOR on Ni-based materials has been hardly explored [22,51]. The analysis below is done provided that Volmer or Heyrosky reactions are rds of HOR in alkaline media-the speculative assumption based on the nonlinear dependence of the HOR kinetics on the surface coverage [34,52]. The HBE value calculated for the facet $\mathrm{Ni}(111),-0.54 \mathrm{eV}$ (Figure 1), is more negative than those calculated for $\mathrm{Pt}$ (111), $\mathrm{Rh}$ (111) and $\mathrm{Ir}(111),-0.37,-0.33$ and $-0.24 \mathrm{eV}$ [30], respectively. In turn, $\mathrm{Pt}$, $\mathrm{Rh}$ and Ir show the highest catalytic activity in HOR in alkaline media, which is more than two orders of magnitude higher than that of Ni electrocatalysts [22]. Thus, based on the predicted optimal HBE value [41] and on the calculated HBE values for the most active catalytic materials [22], the recommended HBE values for the newly designed electrocatalysts should fall into the range between ca. -0.33 to $-0.24 \mathrm{eV}$. In case of Ni-based materials, higher catalytic activity would be expected at the HBE values which are less negative than those for the bare Ni surfaces.

Among the facets, $\mathrm{Pt}$ (100) surpasses the activity of (110) by an order of magnitude, while (111) shows the lowest activity: $(110) \gg(100)>(111)[44,53]$. This sequence could be correlated with the HBE values estimated from the peak potential values for the desorption of the underpotentially deposited hydrogen atom in $0.1 \mathrm{M} \mathrm{KOH}:-0.48 \mathrm{eV}$ for $\mathrm{Pt}(110)$ is much less negative compared to $-0.60 \mathrm{eV}$ for $\mathrm{Pt}(100)[39,49]$. The exchange current density values, $i_{0}$, of carbon supported polycrystalline $\mathrm{Pt}$ nanoparticles, $\mathrm{Pt} / \mathrm{C}$, and bulk polycrystalline $\mathrm{Pt}, \mathrm{Pt}(\mathrm{pc})$, are close to each other $[54,55]$ and to $i_{0}$ for $\mathrm{Pt}$ (110) [44]. Thus, the catalytic activity in HOR might be mainly determined by the presence of the facet $\mathrm{Pt}$ (110). The calculations of the HBE values done for $\mathrm{Pt}(\mathrm{pc})$ show a span within the range of -0.46 [29] and -0.33 [41] eV, while the value of $-0.48 \mathrm{eV}$ is reported for $\mathrm{Pt} / \mathrm{C}$ [56]. Similar order of activity ( $\mathrm{Ni}(110)>\mathrm{Ni}(100)>\mathrm{Ni}(111))$ is observed in the study of Floner et al. [51]: Ni (100) and above all (110) are more active than polycrystalline $\mathrm{Ni}$, whereas the behavior of the latter is close to (111), particularly at low $\mathrm{pH}$ where dissolution of Ni occurs. Based on the results of Floner et al. [51], we assume that $i_{0}$ of the polycrystalline $\mathrm{Ni}_{3} \mathrm{TM}_{1} / \mathrm{C}$ electrocatalysts might be dominated by the facet $\mathrm{Ni}$ (110) or $\mathrm{Ni}$ (220). Interestingly, our calculated HBE values for the bare Ni facets is mostly ordered according to $\mathrm{Ni}(220)>\mathrm{Ni}(200)>\mathrm{Ni}$ (111) (see Figure 1), in good agreement with the activity order experimentally shown by Floner et al. [51]. Furthermore, as seen in Figure 1, it follows that solely alloying Ni with Co results in a positive shift of the HBE value compared to the bare $\mathrm{Ni}$ (111) facet, -0.45 vs. $-0.54 \mathrm{eV}$. For the facet (200), the alloying with $\mathrm{Sc}, \mathrm{Cr}, \mathrm{Fe}, \mathrm{Co}, \mathrm{Cu}$ and $\mathrm{Zn}$ were shown to have a positive effect on the $\mathrm{HBE}$ values, with only $\mathrm{Ni}_{3} \mathrm{Zn}_{1}(-0.19 \mathrm{eV})$ close to the aimed range of $-0.33--0.24 \mathrm{eV} . \mathrm{Ni}_{3} \mathrm{Fe}_{1}, \mathrm{Ni}_{3} \mathrm{Co}_{1}$ and $\mathrm{Ni}_{3} \mathrm{Cu}_{1}$ demonstrate the HBE values close to the earlier reported $\mathrm{Ni}_{3} \mathrm{Ag}_{1}$ [36], CoNi/Mo (110) [29], and Ni/N-CNT [28], the last two materials showing the highest mass specific/surface specific activity values published till now. As regarding the facet (220), the HBE value of $\mathrm{Ni}_{3} \mathrm{~V}_{1}$ falls into the recommended range, and the catalyst might be of interest of the HOR. $\mathrm{Ni}_{3} \mathrm{Fe}_{1}(-0.37 \mathrm{eV})$ and $\mathrm{Ni}_{3} \mathrm{Co}_{1}(-0.35 \mathrm{eV})$ of the facet (220) could also result in better HOR than bare $\mathrm{Ni}$ catalyst, and therefore, they are included in our experimental work for further study. Thus, based on the theoretical predictions (Figure 1), a series of carbon supported binary electrocatalysts $\left(\mathrm{Ni}_{3} \mathrm{Fe}_{1}\right.$, $\mathrm{Ni}_{3} \mathrm{Co}_{1}$ and $\mathrm{Ni}_{3} \mathrm{Cu}_{1}$ ) and monometallic $\mathrm{Ni}$ (as reference material) were synthesized by the chemical reduction method. $\mathrm{Fe}, \mathrm{Co}$ and $\mathrm{Cu}$ were chosen as the TM dopants due to their promising HBE and OHBE values (Tables A4-A6, Appendix A).

\subsection{Physical and Chemical Characterization}

The TEM image (Figure S1a, Supplementary Materials) shows that electrocatalysts are characterized by nanoscopically uniform distribution of near-spherical particles with the average diameter of ca. 
$10 \mathrm{~nm}$ (Figure S1b, Supplementary Materials), surrounded by amorphous carbon support. Assuming spherical particles, the calculated specific surface area of ca. $70 \mathrm{~m}^{2} \mathrm{~g}^{-1} \mathrm{Ni}$ would be expected for a particle average diameter of $10 \mathrm{~nm}$.

For binary $\mathrm{Ni}_{3} \mathrm{TM}_{1} / \mathrm{C}$ catalysts, element mapping revealed nanoscopically non-homogeneous co-distribution of the metallic components (Figures S2-S4, Supplementary Materials). This shows that the chemical reduction method most likely might result in the formation of composite materials (mechanical mixtures), rather than alloys. The most significant heterogeneity was observed for the $\mathrm{Ni}_{3} \mathrm{Cu}_{1} / \mathrm{C}$ catalyst (Figure S4, Supplementary Materials), where separate areas of $\mathrm{Ni}$ (red pixels) and $\mathrm{Cu}$ (green pixels) can be seen. Surface enrichment by $\mathrm{Ni}$ phase (red pixels) was revealed for all the binary $\mathrm{Ni}_{3} \mathrm{TM}_{1} / \mathrm{C}$ systems (Figures S2-S4, Supplementary Materials), which is in good agreement with the X-ray photoelectron spectroscopy (XPS) data (Table S1, Supplementary Materials). The opposite-bulk segregation of $\mathrm{Ni}-$ was observed in binary $\mathrm{Ni}_{9} \mathrm{Mo}_{1} / \mathrm{C}$ electrocatalyst [34]. These observations illustrate that special controlled synthetic approaches are needed in order to synthesize Ni-TM materials with the given Ni-to-TM ratio. Nevertheless, quite homogeneous metal co-distribution topography was observed for the Ni-Fe and Ni-Co couples in $\mathrm{Ni}_{3} \mathrm{Fe}_{1} / \mathrm{C}$ (Figure S2, Supplementary Materials) and $\mathrm{Ni}_{3} \mathrm{Co}_{1} / \mathrm{C}$ (Figure S3, Supplementary Materials) catalyst, respectively. This latter observation might be related to the fact that $\mathrm{Ni}$ co-deposits simultaneously with $\mathrm{Co}$ and Fe due to the reduction potential values. To compare, the standard reduction potentials of $\mathrm{Ni}\left(E_{\mathrm{Ni}^{2+} / \mathrm{Ni}^{0}}^{0}=-0.25 \mathrm{~V}\right)$ and $\mathrm{Co}\left(E_{\mathrm{Co}^{2+} / \mathrm{Co}^{0}}^{0}=-0.28 \mathrm{~V}\right)$ are close, whereas $\mathrm{Cu}$ has much higher potential $\left(E_{\mathrm{Cu}^{0} / \mathrm{Cu}^{0}}=+0.34 \mathrm{~V}\right)$. Consequently, the coexistence of the composites with the alloyed phase(s) in $\mathrm{Ni}_{3} \mathrm{TM}_{1} / \mathrm{C}$ catalysts cannot be ruled out unambiguously. Therefore, a thorough analysis of the XRD patterns of the as-synthesized catalysts and of those after the thermal treatment at $450{ }^{\circ} \mathrm{C}$ was done (Figures S5 and S6, Supplementary Materials). On XRD patterns (Figure S5), catalysts show wide peaks at $\sim 44.5^{\circ}$ of low intensity, which corresponds to Ni (111) facets, the same facet as calculated by DFT (see previous section). Small particle sizes explain the broadening of the (111) peak (with extremely low crystallite sizes of ca. $0.7 \mathrm{~nm}$ ) and the absence of (200) and (220) reflections on the XRD patterns, which does not rule out the coexistence of the high-index facets in the catalysts. The $\mathrm{Ni}(200)$ and $\mathrm{Ni}(220)$ facets are expected to appear at $51.85^{\circ}$ and $76.37^{\circ}$, respectively. All the catalysts are characterized by the presence of hydrated nickel hydroxide $\mathrm{Ni}(\mathrm{OH})_{2} \cdot 0.75 \mathrm{H}_{2} \mathrm{O}$ (ICDD, \#00-038-0715) or nickel oxyhydroxide $\mathrm{Ni}_{5} \mathrm{O}(\mathrm{OH})_{9}$ (ICDD, \#00-027-0340) phase. These phases can be ascribed to the surface oxidation of the catalysts, which potentially may block the electrochemically active surface (see the section below). According to the XPS analysis (Figure S8, Supplementary Materials), the surface of $\mathrm{Ni}$ is predominantly oxidized to $\mathrm{NiO}, \mathrm{Ni}_{2} \mathrm{O}_{3}$ and $\mathrm{Ni}(\mathrm{OH})_{2}$ with the ratio of metallic Ni between 4.5 to 18 at.\% (Table S3, Supplementary Materials). Copper phase in $\mathrm{Ni}_{3} \mathrm{Cu}_{1} / \mathrm{C}$ is partially oxidized forming $\mathrm{Cu}_{2} \mathrm{O}$ (ICDD, \#00-005-0667), which is in an agreement with the XPS data (Figure S7a, Supplementary Materials). The crystallite sizes of metallic copper are ca. $22 \mathrm{~nm}$, which is comparable to the catalyst particle sizes (Figure S1, Supplementary Materials). Shale-up satellites of copper for $\mathrm{Ni}_{3} \mathrm{Cu}_{1} / \mathrm{C}$ catalyst (Figure S7a, Supplementary Materials) are characteristic of divalent $\mathrm{Cu}$, whereas monovalent $\mathrm{Cu}$ has no satellites [57]. The peak at 953.0 can correspond to all three components: Zerovalent $\mathrm{Cu}\left(\mathrm{Cu} 2 \mathrm{p}_{1 / 2}\right.$ at $952.6 \mathrm{eV})$ [58], monovalent ( $\mathrm{Cu} 2 \mathrm{p}_{1 / 2}$ at $\left.952.7 \mathrm{eV}\right)$ [59] or divalent $\mathrm{Cu}\left(\mathrm{Cu} 2 \mathrm{p}_{1 / 2}\right.$ at $\left.952.5 \mathrm{eV}\right)$ [60], as well as the peak at ca. $933 \mathrm{eV}$. High resolution XPS spectrum for $\mathrm{Ni}_{3} \mathrm{Fe}_{1} / \mathrm{C}$ (Figure S7b, Supplementary Materials) shows three distinguishable peaks: A peak of the highest intensity at binding energy (BE) $\sim 712-714 \mathrm{eV}$ which could be ascribed to $\mathrm{Fe}^{3+}$ salts, but most probably arises from Ni LMM Auger peak $(712 \mathrm{eV})$, overlapping with $\mathrm{Fe} 2 \mathrm{p}_{3 / 2}$. The peak of low intensity at $707.9 \mathrm{eV}$ corresponds to metallic $\mathrm{Fe}$ [61]. The broad peak at ca. $725 \mathrm{eV}$ can be ascribed to either $\mathrm{Fe}_{2} \mathrm{O}_{3}\left(\mathrm{Fe} 2 \mathrm{p}_{1 / 2}\right.$ at $\left.724 \mathrm{eV}\right)$ [62], or $\mathrm{FeOOH}$ $\left(\mathrm{Fe} 2 \mathrm{p}_{1 / 2}\right.$ at $724.3 \mathrm{eV}$ ) [62], or $\mathrm{Fe}_{3} \mathrm{O}_{4}\left(\mathrm{Fe} 2 \mathrm{p}_{1 / 2}\right.$ at $723.5 \mathrm{eV}$ ) [62]. It is more challenging to determine the concentration and chemical shifts of cobalt for $\mathrm{Ni}_{3} \mathrm{Co}_{1} / \mathrm{C}$, since $\mathrm{Co} 2 \mathrm{p}_{3 / 2}$ is close to Ni LMM structure and $\mathrm{Co} 3 \mathrm{p}$ spectrum overlaps with the one for $\mathrm{Ni} 3 \mathrm{p}$.

The XRD patterns registered on the as-synthesized $\mathrm{Ni}_{3} \mathrm{TM}_{1} / \mathrm{C}$ catalysts cannot provide clear evidence of metal alloying. Therefore, thermal treatment at $450{ }^{\circ} \mathrm{C}$ in reducing atmosphere was used 
as an indirect indication of the presence of several metallic phases in the as-synthesized materials. The XRD patterns deconvolution for the heat-treated $\mathrm{Ni}_{3} \mathrm{Fe}_{1} / \mathrm{C}$ (Figure S6d, Supplementary Materials) and $\mathrm{Ni}_{3} \mathrm{Cu}_{1} / \mathrm{C}$ (Figure S6c, Supplementary Materials) have shown a splitting of the reflections into two peaks. One of them can be ascribed to the alloy phases enriched by $\mathrm{Ni}$ and by the other-to the second transition metal. For instance, the reflections of $\mathrm{Ni}_{3} \mathrm{Cu}_{1} / \mathrm{C}$ at the 20angles of 44.16, 51.45 and 75.92 are close to those for the alloy $\mathrm{Ni}_{3} \mathrm{Cu}_{1}$ (ICDD, \#04-004-4502), whereas the set of the facets at 43.96, 51.41 and 75.68 is shifted to the metallic $\mathrm{Cu}$ (ICDD, \#00-004-0836) and may correspond to the Cu-rich $\mathrm{Ni}-\mathrm{Cu}$ alloys.

Thus, chemical reduction of the inorganic precursors on carbon support using sodium borohydride as the reducing agent results in the formation of near-spherical nanoparticles with poor crystallinity and the average particle size of ca. $10 \mathrm{~nm}$. In the binary $\mathrm{Ni}_{3} \mathrm{TM}_{1} / \mathrm{C}$ catalysts, heterogeneous co-distribution the metallic components was observed, with partially separated areas of $\mathrm{Cu}_{2} \mathrm{O}$ in $\mathrm{Ni}_{3} \mathrm{Cu}_{1}$, and segregation of $\mathrm{Ni}$ on the surface for all the samples. Homogeneity of the metallic components co-distribution in the bulk of the as-synthesized catalysts and the separation of the XRD reflexes after the thermal treatment at $450{ }^{\circ} \mathrm{C}$ illustrates that the binary $\mathrm{Ni}_{3} \mathrm{TM}_{1} / \mathrm{C}$ catalysts are predominantly composites-mechanical mixtures of either $\mathrm{Ni}$ with $\mathrm{TM}$, or mixture of several $\mathrm{Ni}_{\mathrm{x}} \mathrm{TM}_{\mathrm{y}}$ alloys.

\subsection{Electrochemical Characterization}

Figure 2a shows the first several cycles of the HOR polarization curves (solid lines) on the Ni/C catalyst and compares them with the corresponding cyclic voltammogram recorded in Ar atmosphere (dashed line). Opposed to the behavior of the TM-doped catalysts, bare Ni shows a significant increase of the catalytic activity after the first HOR cycle (Figure 2a), namely after the partial electrochemical oxidation of the surface. The positive effect of the surface pre-oxidation on the Ni catalytic activity in HOR was also reported previously [52,63]. This observation might serve as direct experimental evidence of the bifunctional mechanism of $\mathrm{HOR}[26,50,64-67]$ when $\mathrm{OH}_{\mathrm{ad}}$ species, pre-chemisorbed on the adjacent active sites, are required in order to remove $\mathrm{H}_{\mathrm{ad}}$ chemisorbed on the free metallic surface of $\mathrm{Ni}$, and to make the hydrogen oxidation reaction proceed. Thus, presumably a certain optimal ratio of $\mathrm{Ni}\left(\mathrm{OH}_{\mathrm{ad}}\right) / \mathrm{Ni}\left(\mathrm{H}_{\mathrm{ad}}\right)$ sites is needed to retain the HOR activity of bare Ni electrocatalyst. Therefore, the theoretical estimations of HBE and OHBE, provided in Figure 1a,b, might shed some light on the understanding of the competitive co-adsorption of $\mathrm{H}$ and $\mathrm{OH}$ species (see Section 2.1). Noteworthy, $\mathrm{Ni}_{3} \mathrm{TM}_{1}$ catalysts do not require a preliminary electrooxidation cycle, which might be related either to the fact that the presence of TMs with higher affinity to oxygen (such as $\mathrm{Cu}$ [68], Co [69] and $\mathrm{Fe}$ [69]) stabilizes the oxygenated species on the surface of $\mathrm{Ni}$, or the TMs serve by themselves as the active sites for formation of $\mathrm{OH}_{\text {ad }}$ species. In any case, an important theoretical question arises: Would a hypothetical surface with the optimal value of HBE (discussed earlier) and no affinity to chemisorption of $\mathrm{OH}$ species catalyze HOR in alkaline media? Might it be the case that PGMs (e.g., Pt, $\mathrm{Ir}, \mathrm{Rh}$ ) show two orders of magnitude lower catalytic activity in HOR in alkaline media compared to acidic ones $[45,49,56]$, because in the potential range of hydrogen electrooxidation the surfaces produce a negligibly low ratio PGM $\left(\mathrm{H}_{\mathrm{ad}}\right) / \mathrm{PGM}\left(\mathrm{OH}_{\mathrm{ad}}\right)$ ? The doping of PGMs by TMs with high affinity to chemisorption of $\mathrm{OH}$ species was shown to result in the HOR catalysis promotion $[67,70,71]$. However, this subject is beyond the scope of this work.

HOR polarization curves in the potential range of $0-0.4 \mathrm{~V}$, presented in Figure $3 \mathrm{a}, \mathrm{b}$, show electrocatalytic behavior of $\mathrm{Ni} / \mathrm{C}, \mathrm{Ni}_{3} \mathrm{Fe}_{1} / \mathrm{C}, \mathrm{Ni}_{3} \mathrm{Co}_{1} / \mathrm{C}$ and $\mathrm{Ni}_{3} \mathrm{Cu}_{1} / \mathrm{C}$ typical for polycrystalline $\mathrm{Ni}$ [51], or TM doped Ni electrocatalysts [34]. For all the catalysts, during the forward scan (Figure 2a,b), a peak of HOR is observed, with the current increasing up to certain potential values (see the peak potential values in Figure $2 b$ ). Further, the surface deactivates with the increase of the potential due to the increasing surface electrooxidation, and at $E>0.4 \mathrm{~V}$ there is no catalytic activity in HOR. A similar effect was observed in HOR for $\mathrm{Ru} / \mathrm{C}$ [72] due to the competitive adsorption of $\mathrm{H}_{2}$ and $\mathrm{OH}^{-}$. On the backward scan, the surface of the catalysts reactivates, due to the reversible electrochemical 
reduction of $\mathrm{Ni}$ (see black solid and dashed circles marking the onset of HOR and Ni electroreduction, respectively, on the backward scans).
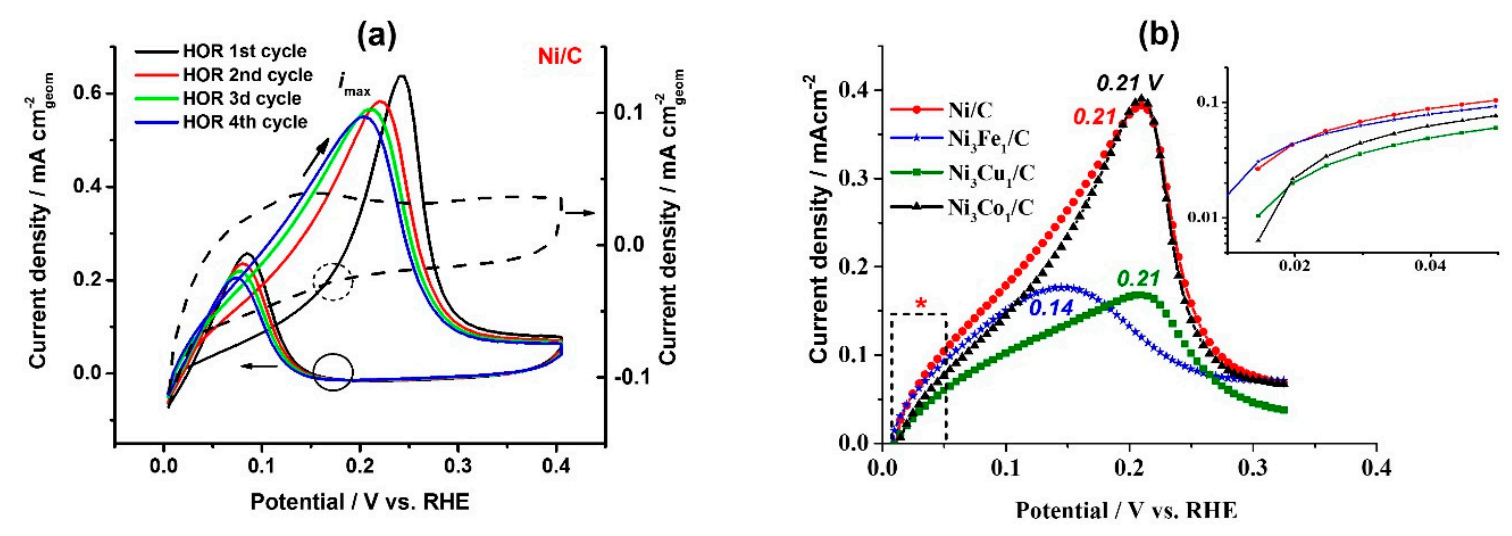

Figure 2. (a) Hydrogen oxidation reaction (HOR) polarization curves (solid lines) and cyclic voltammogram (dashed line) for the $\mathrm{Ni} / \mathrm{C}$ catalyst. The arrows show the potential sweep direction. (b) Comparison of the HOR polarization curves (forward scans) for monometallic Ni/C and bimetallic $\mathrm{Ni}_{3} \mathrm{TM}_{1} / \mathrm{C}$ catalysts for $\mathrm{TM}=\mathrm{Fe}, \mathrm{Co}$ and $\mathrm{Cu}$. The numbers correspond to the peak potential values.

* Potential range of $0.01-0.05 \mathrm{~V}$ used for the kinetic analysis.

The analysis of the HOR kinetics in the micropolarization area $(0.01-0.05 \mathrm{~V})$ reveals a clear effect of the dopant on the exchange current density: At the comparable values of the electrochemical surface area (ECSA), bare $\mathrm{Ni} / \mathrm{C}$ shows $0.039 \mathrm{~mA} \mathrm{~cm}^{-2} \mathrm{Ni}$ (Table 1), whereas addition of $\mathrm{Fe}$, for instance, results in a significant reaction promotion with $0.06 \mathrm{~mA} \mathrm{~cm}^{-2} \mathrm{Ni}$, which in turn positively affects mass specific activity, $1.6 \mathrm{~A} \mathrm{~g}^{-1} \mathrm{Ni}$ vs. $1.87 \mathrm{~g}^{-1} \mathrm{Ni}$ (Table 1). The $i_{0}$ values reported in this work exceed the highest $i_{0}$ values reported earlier in the literature, for instance, $0.028 \mathrm{~mA} \mathrm{~cm}^{-2} \mathrm{Ni}$ for hydrothermally synthesized $70 \% \mathrm{Ni} / \mathrm{N}-\mathrm{CNT}$ [28], or $0.027 \mathrm{~mA} \mathrm{~cm}^{-2} \mathrm{Ni}$ for thermally reduced $50 \% \mathrm{Ni}_{9} \mathrm{Mo}_{1} / \mathrm{C}$ [34] and $0.025 \mathrm{~mA}$ $\mathrm{cm}^{-2} \mathrm{Ni}$ for $50 \% \mathrm{Ni}_{9.5} \mathrm{Cu}_{0.5} / \mathrm{C}$ [73], showing that chemical reduction might be a promising approach for the further development of Ni-based catalysts. However, overall catalyst mass activity of our catalysts is lower $\left(0.35-0.55 \mathrm{~A} \mathrm{~g}^{-1}\right.$ cat $)$ for the binary electrocatalysts compared to the bare $\mathrm{Ni} / \mathrm{C}\left(0.6 \mathrm{~A} \mathrm{~g}^{-1}\right.$ cat $)$, due to the high concentration of the catalytically inert TMs. The mass catalytic values are lower (6.5 $\mathrm{A} \mathrm{g}^{-1}$ cat for $70 \% \mathrm{Ni} / \mathrm{N}-\mathrm{CNT}$ [28], $3.54 \mathrm{~A} \mathrm{~g}^{-1}$ cat for the electrodeposited CoNiMo [29], $2.9 \mathrm{~A} \mathrm{~g}^{-1}$ cat for $50 \% \mathrm{Ni}_{9} \mathrm{Mo}_{1} / \mathrm{C}$ [34]) or comparable (0.94 $\mathrm{A} \mathrm{g}^{-1}$ cat for $25 \% \mathrm{Ni}_{9.5} \mathrm{Cu}_{0.5} /$ Vulcan XC72 [37]) to the published ones. In previous works, the authors have applied preliminary electrochemical reduction of the surface, which allowed increasing the surface area up to $10-20 \mathrm{~m}^{2} \mathrm{~g}^{-1} \mathrm{Ni}$. In our work, we have intentionally avoided the preliminary reduction step in order to demonstrate that carbon supported nanoparticles synthesized via simple chemical reduction method at $\sim 0^{\circ} \mathrm{C}$ can be handled in ambient atmosphere, and they can still retain their electrocatalytic activity, opposed, for instance, to the thermally obtained Ni-based electrocatalysts [34].

Table 1. Comparison of surface area values and the HOR electrocatalytic properties for different catalysts.

\begin{tabular}{|c|c|c|c|c|c|c|c|c|}
\hline \multirow{2}{*}{ Catalyst } & \multirow{2}{*}{$\mathrm{ESCA} / \mathrm{m}^{2} \mathrm{~g}^{-1} \mathrm{Ni}$} & \multicolumn{4}{|c|}{$i$ at $\eta=0.05 \mathrm{~V}$} & \multicolumn{3}{|c|}{$i_{\mathrm{o}}$} \\
\hline & & $\mathrm{mA} \mathrm{cm}^{-2}$ geom & $\mathrm{A} \mathrm{g}^{-1}$ cat & $\mathrm{Ag}^{-1} \mathrm{Ni}$ & $\mathrm{A} \mathrm{m}^{-2} \mathrm{Ni}$ & $\mathrm{Ag}^{-1} \mathrm{Ni}$ & $\mathrm{mA} \mathrm{cn}$ & ${ }^{-2} \mathrm{Ni}$ \\
\hline $\mathrm{Ni} / \mathrm{C}$ & $1.3 \pm 0.2$ & 0.12 & 0.6 & 1.60 & 0.347 & 0.83 & 0.039 & $\begin{array}{l}+0.018 \\
-0.013\end{array}$ \\
\hline $\mathrm{Ni}_{3} \mathrm{Fe}_{1} / \mathrm{C}$ & $1.2 \pm 0.6$ & 0.11 & 0.55 & 1.87 & 0.858 & 0.96 & 0.060 & $\begin{array}{l}+0.008 \\
-0.008\end{array}$ \\
\hline $\mathrm{Ni}_{3} \mathrm{Cu}_{1} / \mathrm{C}$ & $1.2 \pm 0.2$ & 0.09 & 0.45 & 2.01 & 0.510 & 0.98 & 0.051 & $\begin{array}{l}+0.001 \\
-0.0012\end{array}$ \\
\hline $\mathrm{Ni}_{3} \mathrm{Co}_{1} / \mathrm{C}$ & $1.5 \pm 0.3$ & 0.07 & 0.35 & 1.28 & 0.290 & 0.66 & 0.020 & $\begin{array}{l}+0.030 \\
-0.003\end{array}$ \\
\hline
\end{tabular}


Figure 3a-d shows the linear potential stripping (solid lines) for the catalysts under Ar atmosphere at the same potential sweep rate $\left(1 \mathrm{mV} \mathrm{s}^{-1}\right)$ used to record the HOR polarization curves, and the corresponding derivatives of the HOR polarization curves (dashed lines), for all the catalysts. The charge consumed for the full surface coverage by $\mathrm{Ni}(\mathrm{OH})_{2}$ (the area under the solid line peaks, was used to estimate ECSA of Ni. The ECSA values are presented in Table 1. Extremely low ECSA values were obtained in all catalysts $\left(<2 \mathrm{~m}^{2} \mathrm{~g}^{-1} \mathrm{Ni}\right.$ compared to the expected $\sim 70 \mathrm{~m}^{2} \mathrm{~g}^{-1} \mathrm{Ni}$ based on TEM images, Figure S1, Supplementary Materials), which are probably due to the oxidative surface passivation evidenced by EDS (Table S1, Supplementary Materials) and XPS (Tables S1 and S3, Figure S8, Supplementary Materials).
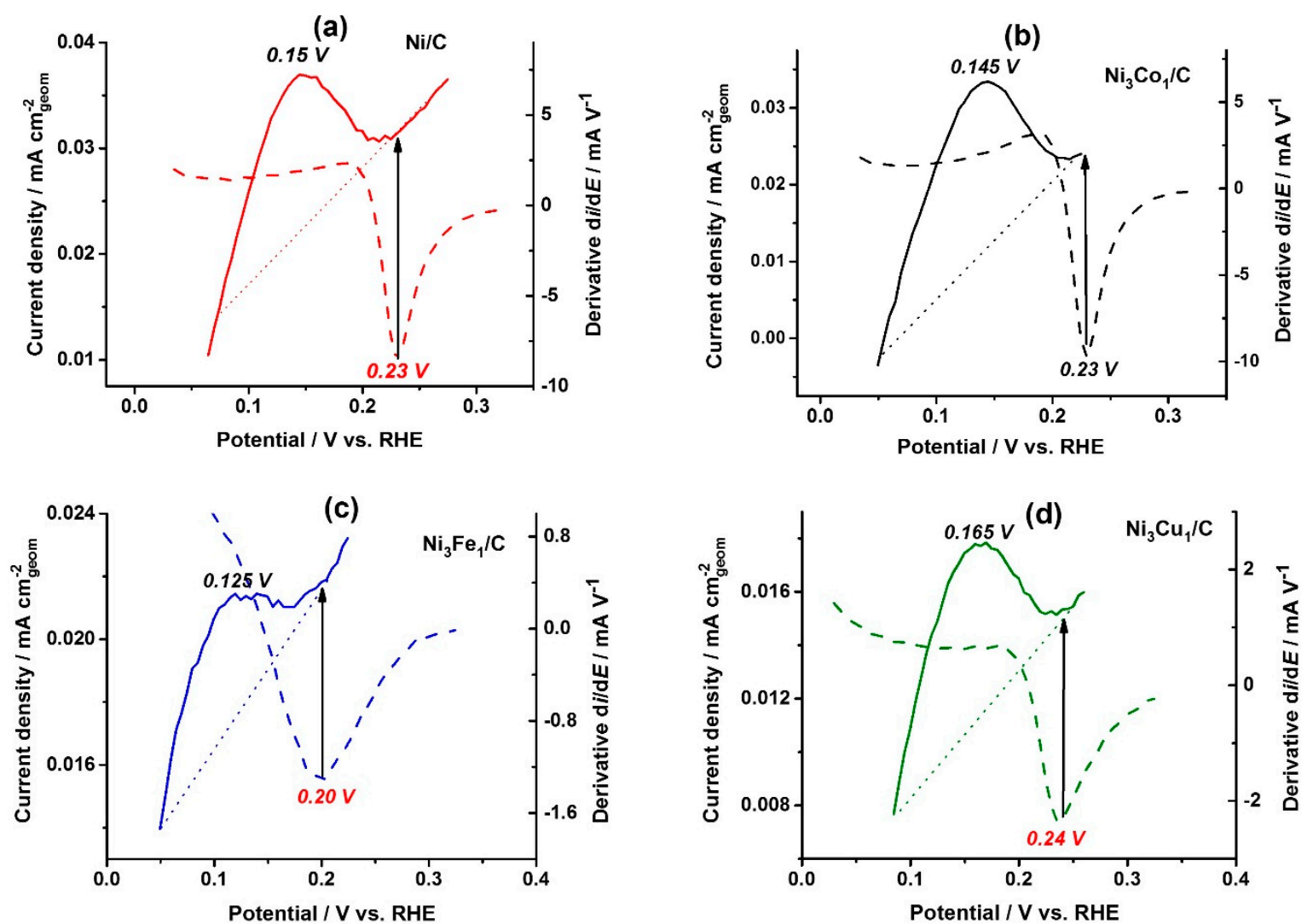

Figure 3. Linear potential stripping (solid lines) for the $\mathrm{Ni} / \mathrm{C}(\mathbf{a}), \mathrm{Ni}_{3} \mathrm{Co}_{1} / \mathrm{C}(\mathbf{b}), \mathrm{Ni}_{3} \mathrm{Fe}_{1} / \mathrm{C}(\mathbf{c})$ and $\mathrm{Ni}_{3} \mathrm{Cu}_{1} / \mathrm{C}(\mathrm{d})$ catalysts under Ar atmosphere and the corresponding derivatives (dashed lines) of the HOR polarization curves. Numbers indicate the peak potential values.

The HOR polarization curves (Figure 2b) were differentiated, and the potential values corresponding to the minimum of the derivatives (dashed lines, Figure 3a-d) were used as one of the catalyst characteristic parameters, showing the potential of the catalytic activity loss. As seen from Figure 3a-d, the potentials of the derivative minimum (marked in red: $0.23,0.23,0.20$ and $0.24 \mathrm{~V}$ for on the bare $\mathrm{Ni} / \mathrm{C}$, $\mathrm{Ni}_{3} \mathrm{Co}_{1} / \mathrm{C}, \mathrm{Ni}_{3} \mathrm{Fe}_{1} / \mathrm{C}$, and $\mathrm{Ni}_{3} \mathrm{Cu}_{1} / \mathrm{C}$, respectively) correspond to the full surface coverage (indicated by black arrows). Full surface coverage by monolayer of $\mathrm{Ni}(\mathrm{OH})_{2}$ on the bare $\mathrm{Ni} / \mathrm{C}, \mathrm{Ni}_{3} \mathrm{Co}_{1} / \mathrm{C}$ and $\mathrm{Ni}_{3} \mathrm{Cu}_{1} / \mathrm{C}$ takes place at more anodic potential $(0.23,0.23$ and $0.24 \mathrm{~V}$, respectively, Figure $3 \mathrm{a}, \mathrm{b}, \mathrm{d})$, whereas the surface of $\mathrm{Ni}_{3} \mathrm{Fe}_{1} / \mathrm{C}$ is fully covered already at $0.20 \mathrm{~V}$ (Figure 3c). The peak potential of $\mathrm{Ni}_{3} \mathrm{Fe}_{1} / \mathrm{C}$ electrooxidation (solid line, Figure $3 \mathrm{c}$ ), $0.125 \mathrm{~V}$, is negatively shifted as well compared to $\mathrm{Ni} / \mathrm{C}$ (Figure 3a), $\mathrm{Ni}_{3} \mathrm{Co}_{1} / \mathrm{C}$ (Figure $3 \mathrm{~b}$ ) and $\mathrm{Ni}_{3} \mathrm{Cu}_{1} / \mathrm{C}$ (Figure $4 \mathrm{~d}$ ). Thus, Ni-Fe catalysts are prone to the higher $\mathrm{OH}_{\mathrm{ad}}$ coverage at lower overpotentials, which results in higher HOR catalytic activity at lower overpotential values (Figure 3b, insert). 

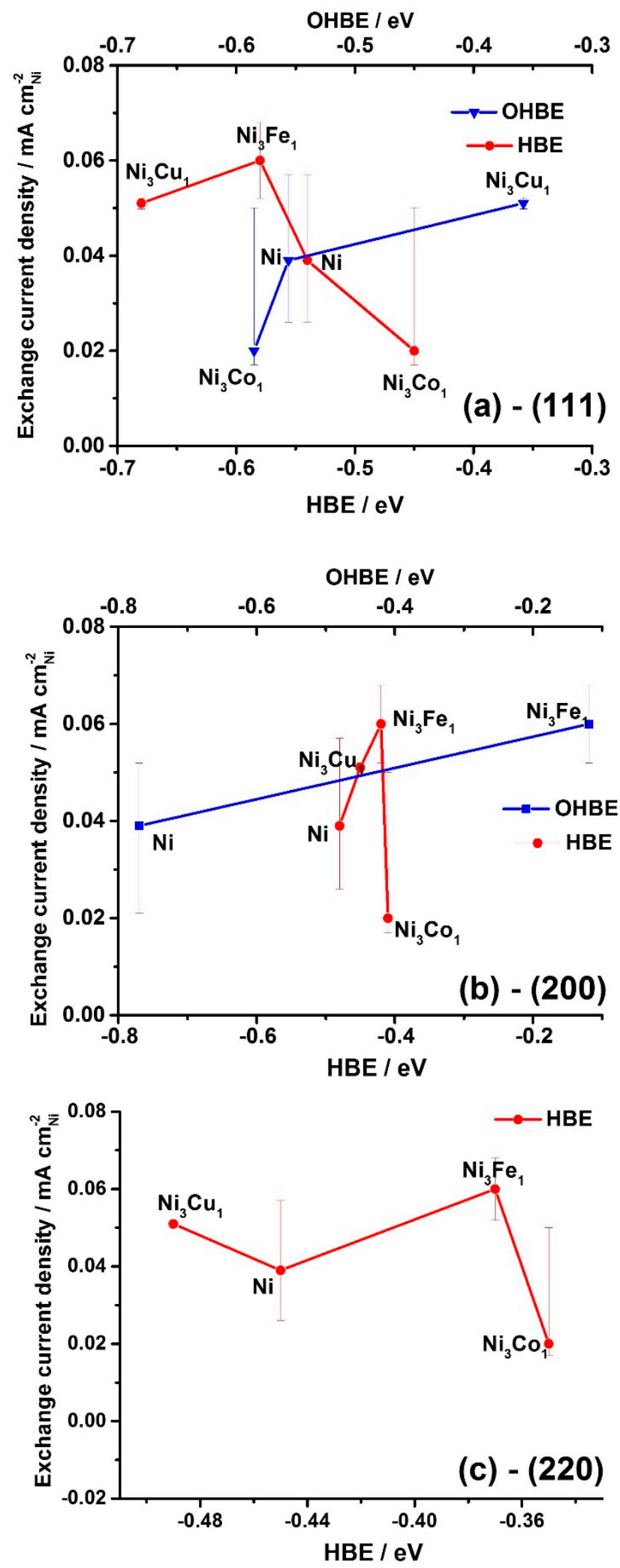

Figure 4. Correlation between the experimentally determined exchange current density values of the catalysts with the theoretically predicated HBE and OHBE values: (a) (111) facet, (b) (200) facet, and (c) (220) facet.

Figure 4a shows the general trend of decrease in exchange current density values with the HBE value increase for the facet (111), whereas the opposite trend is expected (see Section 2.1. Theoretical 
prediction). At the same time, the expected catalytic activity increase is observed with the increase of HBE for the facets (200) and (220) (Figure $4 b, c)$. This observation might indicate that the catalytic activity is predominantly determined by higher index surfaces, (200) and (220). Figure $5 \mathrm{a}, \mathrm{b}$ also show that $i_{\mathrm{o}}$ increases as OHBE values increase. The latter observation might serve as indirect evidence of the bifunctional mechanism of the HOR hypothesized earlier in different studies $[25,26,64]$ explaining the promotion effect of the dopants on the HOR kinetics. According to this bifunctional mechanism, there is a need for more than the conventional HBE indicator to describe the HOR in alkaline [22] - the OHBE indicator may bring the missing parameter to clearly understand the HOR kinetics and mechanism.

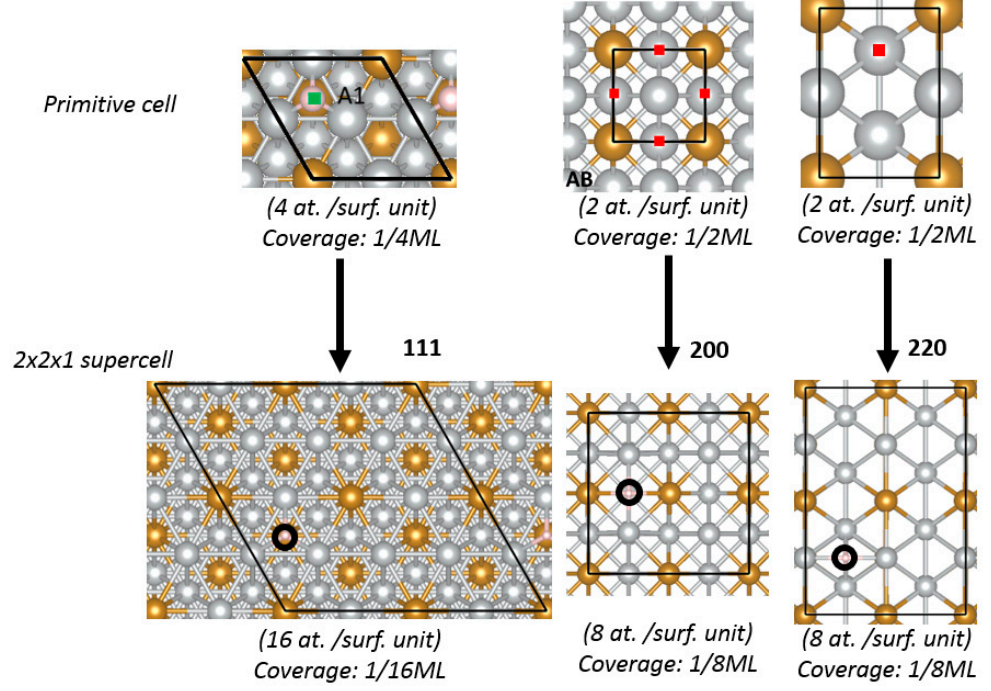

Figure 5. Slab models for all three $\mathrm{Ni}_{3} \mathrm{TM}_{1}$ (111), (200) and (220) facets constructed from the primitive cell. The locations marked by black circles indicate the $\mathrm{H}$ adsorption sites with the lowest energy.

This study provides an initial thought supported with some first data on HBE and OHBE, both as important parameters to describe the electrocatalytical activity of Ni-based catalysts towards HOR in alkaline medium. Further DFT calculations and experimental studies of specifically Ni-TM facets are needed to increase this understanding.

\section{Materials and Methods}

\subsection{Computational Details}

Spin-polarized DFT calculations were performed with the Vienna Ab Initio Simulation Package (VASP) [74,75]. We use the Perdew-Burke-Ernzerhof (PBE) [76] of the general gradient approximation (GGA) exchange-correlation functional in all computational calculations. This functional describes well all the chosen transition metal alloys [77-80]. Projected augmented wave (PAW) potentials [81,82] represented frozen core electrons and nuclei for each atom. For the whole first row $3 \mathrm{~d}$ TM, including Sc, $\mathrm{Ti}, \mathrm{V}, \mathrm{Cr}, \mathrm{Mn}, \mathrm{Fe}, \mathrm{Co}, \mathrm{Ni}, \mathrm{Cu}$ and $\mathrm{Zn}$ atoms, the appropriate PAW potentials for inner shell electrons are replaced with Ar's electronic configuration. Kohn-Sham (KS) equations were solved with a plane-wave basis. Symmetry operations were imposed for a better description of the geometry. $k$-space integration was performed with the tetrahedron method with Blöchl corrections [82].

We used a $k$-mesh of $3 \times 3 \times 1$ in the Monkhorst-Pack scheme and an energy cutoff of $400 \mathrm{eV}$ for the plane-wave basis set. These $k$-grids and energy cutoffs were converged to a total energy lower than $1 \mathrm{meV}$ atom $^{-1}$. For all of the calculations, we relaxed the cells using convergence criteria of $10^{-5} \mathrm{eV}$ for electronic iterations and of $0.01 \mathrm{eV}^{-1}$ for ionic iterations. Geometrical relaxations took place with a conjugate gradient algorithm [83]. All slabs were separated from their periodic image by a minimum of $16 \AA$ vacuum layers, which is converged the total energy up to $0.1 \mathrm{meV}^{\text {atom }}{ }^{-1}$. 
The unit cells of the catalytic materials were built with $25 \%$ of TM (i.e., atomic ratio Ni:TM = 3:1), with an FCC structure. We considered three facets that have been experimentally observed in the XRD patterns (Figures S5 and S6, Supplementary Materials) of the electrocatalysts: $\mathrm{Ni}_{3} \mathrm{TM}_{1}$ facets (111), (200), and (220). The (111) and (200) facets were modeled by a five-layer slab, while the (220) facet needed seven layers to converge the calculated adsorption energies. The hydrogen and $\mathrm{OH}$ adsorbate coverage corresponds to a low coverage of $1 / 16$ monolayer (ML) for (111) and 1/8 ML for (200) and (220) surfaces, with supercell size of $2 \times 2 \times 1$ (see Figure 5). The adsorbed hydrogen atoms and the top three layers of the slab were fully relaxed during energy relaxation by selecting several initial hydrogen positions and performing geometry optimization, until forces on all atoms reached the convergence threshold of $0.01 \mathrm{eV} \AA^{-1}$. The rest of the atoms in the slab were fixed on its bulk lattice configuration since adding more atoms gave the same hydrogen binding energies. The most stable $\mathrm{H}$ adsorption sites found for $\mathrm{Ni}_{3} \mathrm{Fe}_{1}$ were adopted and used for all the $\mathrm{Ni}_{3} \mathrm{TM}_{1}$ systems. All the optimized ground state structures of bare and adsorbed hydrogen surfaces of $1 \times 1$ primitive cells and $2 \times 2 \times 1$ sized supercell are listed in the Supplementary Materials.

\subsection{Catalyst Synthesis}

Monometallic $\mathrm{Ni} / \mathrm{C}$ and bimetallic $\mathrm{Ni}_{3} \mathrm{TM}_{1} / \mathrm{C}$ carbon-supported electrocatalysts were synthesized via the chemical reduction method at $0{ }^{\circ} \mathrm{C}$, using sodium borohydride as the reducing agent. To synthesize monometallic catalyst, $100 \mathrm{mg}$ of VXCMAX22 (Cabot, Boston, MA, USA) carbon black, noted as C, was suspended in $15 \mathrm{~mL}$ of isopropanol (HPLC Plus GC, 99.9\%, Sigma Aldrich, St. Louis, MI, USA) in the ultrasound bath (XUBA3, Grant Instruments, Cambridge, UK) and then mixed with $15 \mathrm{~mL}$ aqueous solutions containing $1.7 \mathrm{mmol}$ of $\mathrm{NiCl}_{2} \cdot 6 \mathrm{H}_{2} \mathrm{O}(99.3 \%$, Alfa Aesar, Ward Hill, MA, USA). The mixture was cooled down in the ice-bath and deaerated by flowing $\operatorname{Ar}(99.999 \%$, Maxima, Ashdod, Israel). For the synthesis of bimetallic $\mathrm{Ni}_{3} \mathrm{TM}_{1} / \mathrm{C}$ catalysts, $15 \mathrm{~mL}$ of the solutions containing $0.567 \mathrm{mmol}$ of either $\mathrm{FeCl}_{2} \cdot 4 \mathrm{H}_{2} \mathrm{O}$ (99.95\%, Sigma Aldrich), or $\mathrm{CoCl}_{2} \cdot 6 \mathrm{H}_{2} \mathrm{O}(99.99 \%$, Alfa Aesar), or $\mathrm{CuSO}_{4} \cdot 5 \mathrm{H}_{2} \mathrm{O}$ (for analysis, Merck, Kenilworth, NJ, USA) were added to the carbon- $\mathrm{NiCl}_{2}$ mixture. The intended weight ratio of nickel to carbon in monometallic Ni/C catalyst was 0.5 -to-0.5 The same Ni-to-C weight ratio was kept for the bimetallic $\mathrm{Ni}_{3} \mathrm{TM}_{1} / \mathrm{C}$ catalysts, where the atomic ratio of Ni-to-TM was 3-to-1. Ice-cold solution containing 3.4 mmol of $\mathrm{NaBH}_{4}(99.99 \%$, Sigma Aldrich) in $25 \mathrm{~mL}$ of $0.1 \mathrm{M} \mathrm{KOH}$ (AR, Bio-Lab Ltd., Jerusalem, Israel) was used as the reducing agent. The reduction of the metal precursors was carried out in the ice bath by dropping $\mathrm{NaBH}_{4}$ solution into the mixture while stirring. The precipitates were separated in the centrifuge (Eppendorf 5804, Hamburg, Germany). After being rinsed by milli-Q $\mathrm{H}_{2} \mathrm{O}(18.2 \mathrm{M} \Omega \times \mathrm{cm})$ five times at $10,000 \mathrm{rpm}$ for $10 \mathrm{~min}$, the samples were placed in the vacuum oven (1407-2, MRC, Holon, Israel) at r.t. and then dried at $80-90{ }^{\circ} \mathrm{C}$ for $24 \mathrm{~h}$. Before removing the samples from the vacuum, the oven was cooled back to room temperature. The samples were stored in a desiccator under vacuum and handled in the ambient air.

\subsection{Physical and Chemical Characterization}

TEM images were obtained on FEI Tecnai T20 $\mathrm{LaB}_{6}$ microscope operated at $200 \mathrm{kV}$. Catalyst powders were dispersed in isopropanol $\left(2 \mathrm{mg}_{\text {cat }}\right.$ per $\left.10 \mathrm{~mL}\right)$ in ultrasound bath for $2 \mathrm{~h}$, spray-casted onto a 300 mesh Cu grid coated with holey carbon (300 mesh, Agar Scientific, Stansted, UK), and then left to dry on the TEM grids at room temperature.

EDS spectra, STEM images and elemental mapping were collected on Zeiss Ultra-Plus HRSEM. EDS spectra were measured at accelerating voltages in the range of $5-15 \mathrm{kV}$ with the data collecting time 50-150 s. STEM element mapping was done at $30 \mathrm{kV}$ on holey carbon 200 mesh Cu TEM grids (Agar Scientific) with the applied catalysts.

XRD data were collected using Rigaku Smartlab diffractometer with $\mathrm{Cu}$ X-ray source $(\lambda=1.5406 \AA$ ). $X R D$ patterns were recorded in medium resolution parallel beam geometry at the tube current of $100 \mathrm{~mA}$ and tube voltage of $35 \mathrm{kV}$ in $\theta / 2 \theta$ scan mode with the scan rate of $1 \mathrm{deg} . \mathrm{min}^{-1}$ and 
step0.01 deg. The structural data were compared to the ICDD database. Crystallite sizes were estimated using Scherrer's equation [84].

XPS measurements were performed in ultra-high $2.5 \times 10^{-10}$ Torr base pressure) using a 5600 Multi-Technique System (PHI, Chanhassen, MN, USA). The samples were irradiated with an $\mathrm{AlK}_{\alpha}$ monochromated source $(1486.6 \mathrm{eV})$ and the outcome electrons were analyzed by a Spherical Capacitor Analyzer using a slit aperture of $0.8 \mathrm{~mm}$. Survey spectra were registered in a wide energy range $(0-1400 \mathrm{eV})$ at a low resolution. Utility multiplex spectra were taken for different peaks in a low energy range window at an intermediate (utility) resolution. Atomic concentration was calculated for all the elements present. Atomic concentration calculation accuracy was $\pm 2, \pm 5, \pm 10$ and $\pm 20 \%$ for atomic concentrations around $50 \%, 20 \%, 5 \%$ and $1 \%$, respectively.

\subsection{Electrochemical Characterization}

Rotating disc electrode (RDE) method and cyclic voltammetry (CV) were applied to characterize the electrochemical properties of the catalysts using WaveDriver 20 Bipotentiostat/Galvanostat (Pine Research). For RDE tests, Nafion was used as only ionomer, to avoid surface adsorption effects of other ionomers onto the catalysts under study [85]. For these tests, $10 \mathrm{mg}$ of the catalyst was suspended in $2 \mathrm{~mL}$ of isopropanol/water mixture (3/1 vol.). Nafion (10 wt.\% in $\mathrm{H}_{2} \mathrm{O}, \rho=1.05 \mathrm{~g} \mathrm{~mL}^{-1}$, Sigma Aldrich) was added to the catalyst to get a Nafion/catalyst weight ratio of $0.15 / 1$. The suspension was then drop-casted on glassy carbon disc $(5.0 \mathrm{~mm}$, PTFE shroud, Pine Research) to form a catalyst layer with a loading of $200 \mu \mathrm{g}_{\mathrm{cat}} \mathrm{cm}^{-2}$. The electrode was dried in the air for about $1 \mathrm{~h}$ and mounted on the rotating shaft. The experiments were conducted at $25^{\circ} \mathrm{C}$ in $1 \mathrm{M} \mathrm{KOH}$ aqueous solution in a water-jacketed electrochemical cell. Pt wire (Pine Research) isolated in a glass-fritted tube was used as the counter electrode. All the potential values were registered vs. $\mathrm{Hg} / \mathrm{HgO} / 1 \mathrm{M} \mathrm{KOH}$ (RE-61AP, ALS Co., Tokyo, Japan).

Taking into account electrochemical properties of $\mathrm{Ni}$, the following experimental protocol was elaborated using RDE and CV methods. Before immersing the working electrode into the electrolyte, it was purged by $\mathrm{H}_{2}$ (electrolyzer $\mathrm{SPH}-500, \mathrm{H}_{2}$ purity $99.999 \%, \mathrm{H}_{2}$ flow $0-500 \mathrm{~mL} \mathrm{~min}^{-1}$, Jinan Mao An Instrument Co., Ltd., Jinan, China) until the open circuit potential stabilized. The potential was then scanned repeatedly (up to 5 cycles) in the potential range between $0 \mathrm{~V}$ and $0.4 \mathrm{~V}$ vs. RHE, with the sweep rate of $1 \mathrm{mV} \mathrm{s}^{-1}$ and at a rotation speed of $1100 \mathrm{rpm}$, to register the HOR polarization curves. The values of exchange current density $\left(i_{0}\right)$ were calculated in the micropolarization potential range applying Equation (1) [50]:

$$
i_{0} \times\left(\alpha_{\mathrm{c}}+\alpha_{\mathrm{a}}\right)=\frac{R T}{F} \times \frac{i}{\eta}
$$

where $\alpha_{\mathrm{a}}$ and $\alpha_{\mathrm{c}}$ are the anodic and cathodic transfer coefficients, respectively, $i$ is catalytic activity averaged for the range of overpotential values $\left(\eta\right.$ ) between 5 to $50 \mathrm{mV}$ (in $\mathrm{A} \mathrm{cm}{ }^{-2} \mathrm{Ni}$ ), $T$ is the temperature of the electrolyte $(\mathrm{K}), R$ is the gas constant and $F$ is the Faraday constant. Afterwards, the gas flow was changed to Ar until the open circuit potential was stabilized, and then the potential was swept in the potential range between $0 \mathrm{~V}$ and $0.4 \mathrm{~V}$ vs. RHE at the rate of $1 \mathrm{mV} \mathrm{s}^{-1}$. The anodic peak was integrated and used as the in situ method to determine the electrochemical active surface area of $\mathrm{Ni}$ with the specific charge density of $514 \mu \mathrm{C} \mathrm{cm}{ }^{-2} \mathrm{Ni}$ [28].

\section{Conclusions}

Carbon supported nanoparticles of monometallic Ni catalyst and binary Ni-Transition Metal electrocatalytic composites were synthesized via chemical reduction method. Different TM dopants $(\mathrm{Fe}, \mathrm{Co}$ and $\mathrm{Cu})$ were studied in this work. The chemical composition, structure and morphology of the materials were characterized and related to the electrochemical properties towards HOR in alkaline medium. For the first time, both HBE and OHBE values were calculated for this kind of catalysts. DFT calculations showed the significant effect of the dopant TM onto the HBE and OHBE values of the different Ni-TM catalysts, which in turn affects their exchange current densities. It is proposed that 
both HBE and OHBE parameters will be used as the indicators of the electrocatalytic activity of Ni-TM catalysts towards a better understanding of these catalysts for the electrooxidation of hydrogen in alkaline medium.

A significant role of the dopant TM in the promotion of the hydrogen electrooxidation kinetics of the binary Ni-TM/C composites was revealed. A record-high in exchange current density value, $0.060 \mathrm{~mA} \mathrm{~cm}{ }^{2} \mathrm{Ni}$, was observed for $\mathrm{Ni}_{3} \mathrm{Fe}_{1} / \mathrm{C}$. We therefore suggest that $\mathrm{Ni}-\mathrm{Fe} / \mathrm{C}$ could be a promising catalyst for HOR in alkaline media. Development of synthesis approaches and corresponding conditions to minimize surface oxidation of the metallic $\mathrm{Ni}$ in the Ni-TM/C materials may lead to the development of highly active HOR catalysts for PGM-free AEMFCs.

Supplementary Materials: The following are available online at http:/ /www.mdpi.com/2073-4344/8/10/454/s1, Figure S1. (a) Electron microscopy images of $\mathrm{Ni}_{3} \mathrm{Fe}_{1}$ catalyst; (b) Particles size distribution for $\mathrm{Ni}_{3} \mathrm{Fe}_{1}$ catalyst; Figure S2. STEM images of $\mathrm{Ni}_{3} \mathrm{Co}_{1} / \mathrm{C}$ : (a) Electron image; (b) Element map overlapping: Ni: red; Co: green; $\mathrm{Ni}+$ $\mathrm{Co}$ : yellow/orange; (c) Element mapping of $\mathrm{Ni}$; (d) Element mapping of $\mathrm{Co}$; Figure S3. STEM images of $\mathrm{Ni}_{3} \mathrm{Cu}_{1} / \mathrm{C}$ : (a) Electron image; (b) Element map overlapping: $\mathrm{Ni}$ : red; $\mathrm{Cu}$ : green; $\mathrm{Ni}+\mathrm{Cu}$ : yellow/orange; (c) Element mapping of $\mathrm{Ni}$; (d) Element mapping of $\mathrm{Cu}$; Figure S4. STEM images of $\mathrm{Ni}_{3} \mathrm{Fe}_{1} / \mathrm{C}$ : (a) Electron image; (b) Element map overlapping: Ni: red; Fe: green; $\mathrm{Ni}+\mathrm{Fe}$ : yellow/orange; (c) Element mapping of $\mathrm{Ni}$; (d) Element mapping of $\mathrm{Fe}$; Figure S5. The main reflections of the XRD patterns for the as-synthesized monometallic Ni/C catalyst and bimetallic $\mathrm{Ni}_{3} \mathrm{TM}_{1} / \mathrm{C}$ composites; Figure S6. The main reflections of the XRD patterns for monometallic $\mathrm{Ni} / \mathrm{C}$ catalyst and bimetallic $\mathrm{Ni}_{3} \mathrm{TM}_{1} / \mathrm{C}$ composites after the thermal treatment at $450{ }^{\circ} \mathrm{C}$ in the mixture of $10 \% \mathrm{H}_{2} / \mathrm{Ar}$; Figure S7. HR-XPS spectra for $\mathrm{Cu}$ of the catalyst $\mathrm{Ni}_{3} \mathrm{Cu}_{1} / \mathrm{C}(\mathbf{a})$ and $\mathrm{Fe}$ of the catalyst $\mathrm{Ni}_{3} \mathrm{Fe}_{1} / \mathrm{C}$ (b); Figure S8. Deconvolution of HR-XPS spectra of Ni 2 $\mathrm{p}_{3 / 2}$; Table S1. Elemental composition of the catalysts (in at.\%) based on the EDS and XPS data; Table S2. Elemental composition of the catalysts (in wt.\%) based on the EDS data; Table S3. Elemental composition of the catalysts (in at.\%) based on the HR-XPS Ni2 $\mathrm{p}_{3 / 2}$ spectra deconvolution.

Author Contributions: Synthesis, electrochemical measurements, TEM, SEM, STEM, XRD, data analysis, writing and editing, E.S.D.; Funding acquisition, supervision, review and editing, D.R.D.; DFT HBE calculations, J.Z.; DFT OHBE calculations, K.D.; DFT supervision, DFT funding acquisition, review and editing, M.C.T.

Funding: This work was partially funded by the Nancy \& Stephan Grand Technion Energy Program (GTEP); by the European Union's Horizon 2020 research and innovation program [grant No. 721065]; by the Ministry of Science, Technology \& Space of Israel through the M.Era-NET Transnational Call 2015, NEXTGAME project [grant No. 3-12940] and through grant No. 3-12948; by the Israel Science Foundation (ISF) [grant No. 1481/17]; by the Russell Berrie Nanotechnology Institute, Technion; and by the Planning \& Budgeting Committee/ISRAEL Council for Higher Education (CHE) andFuel Choice Initiative (Prime Minister Office of ISRAEL), within the framework of "Israel National Research Center for Electrochemical Propulsion (INREP)". This research was also partially carried out within the framework of the UConn-Technion Energy Collaboration initiative, supported by the Satell Family Foundation, the Maurice G. Gamze Endowed Fund (at the American Technion Society), Larry Pitt and Phillis Meloff, The Eileen and Jerry Lieberman UConn/Israel Global Partnership Fund and the Grand Technion Energy Program (GTEP).

Conflicts of Interest: The authors declare no conflict of interest.

\section{Appendix A}

Table A1. Ground state energies of bare metal/alloy and one with hydrogen at (111) facet (1/16 ML) supercell $2 \times 2 \times 1$ and calculated HBE (all energies are in $\mathrm{eVs}$ ).

\begin{tabular}{cccc}
\hline Material & Bare (111) Facet & Surface with Hydrogen & HBE/eV \\
\hline $\mathrm{Ni}_{3} \mathrm{Sc}_{1}$ & -465.27 & -469.42 & -0.77 \\
$\mathrm{Ni}_{3} \mathrm{Ti}_{1}$ & -498.92 & -503.16 & -0.86 \\
$\mathrm{Ni}_{3} \mathrm{~V}_{1}$ & -500.72 & -504.57 & -0.47 \\
$\mathrm{Ni}_{3} \mathrm{Cr}_{1}$ & -496.02 & -500.10 & -0.70 \\
$\mathrm{Ni}_{3} \mathrm{Mn}_{1}$ & -494.24 & -498.32 & -0.69 \\
$\mathrm{Ni}_{3} \mathrm{Fe}_{1}$ & -479.68 & -483.64 & -0.58 \\
$\mathrm{Ni}_{3} \mathrm{Co}_{1}$ & -447.09 & -450.93 & -0.45 \\
$\mathrm{Ni}_{1}$ bare & -414.05 & -417.97 & -0.54 \\
$\mathrm{Ni}_{3} \mathrm{Cu}$ & -380.83 & -384.90 & -0.68 \\
$\mathrm{Ni}_{3} \mathrm{Zn}_{1}$ & -344.05 & -348.73 & -1.29 \\
\hline
\end{tabular}


Table A2. Ground state energies of bare and with hydrogen at (200) facet (1/8 ML) supercell $2 \times 2 \times 1$ and calculated HBE (all energies are in $\mathrm{eVs}$ ).

\begin{tabular}{cccc}
\hline Material & Bare (200) Facet & Surface with Hydrogen & HBE/eV \\
\hline $\mathrm{Ni}_{3} \mathrm{Sc}_{1}$ & -236.96 & -240.79 & -0.44 \\
$\mathrm{Ni}_{3} \mathrm{Ti}_{1}$ & -251.89 & -255.84 & -0.57 \\
$\mathrm{Ni}_{3} \mathrm{~V}_{1}$ & -251.01 & -254.94 & -0.55 \\
$\mathrm{Ni}_{3} \mathrm{Cr}_{1}$ & -251.46 & -255.31 & -0.47 \\
$\mathrm{Ni}_{3} \mathrm{Mn}_{1}$ & -251.86 & -255.78 & -0.54 \\
$\mathrm{Ni}_{3} \mathrm{Fe}_{1}$ & -241.93 & -245.73 & -0.42 \\
$\mathrm{Ni}_{3} \mathrm{Co}_{1}$ & -222.10 & -225.89 & -0.41 \\
$\mathrm{Ni}_{\text {bare }}$ & -203.61 & -207.47 & -0.48 \\
$\mathrm{Ni}_{3} \mathrm{Cu}_{1}$ & -184.70 & -188.53 & -0.45 \\
$\mathrm{Ni}_{3} \mathrm{Zn}_{1}$ & -164.37 & -167.95 & -0.19 \\
\hline
\end{tabular}

Table A3. Ground state energies of bare and with hydrogen at (220) facet (1/8 ML) supercell $2 \times 2 \times 1$ and calculated HBE (all energies are in eVs).

\begin{tabular}{cccc}
\hline Material & Bare (220) Facet & Surface with Hydrogen & HBE/eV \\
\hline $\mathrm{Ni}_{3} \mathrm{Sc}_{1}$ & -328.56 & -332.63 & -0.69 \\
$\mathrm{Ni}_{3} \mathrm{Ti}_{1}$ & -349.00 & -352.35 & 0.04 \\
$\mathrm{Ni}_{3} \mathrm{~V}_{1}$ & -349.56 & -353.17 & -0.22 \\
$\mathrm{Ni}_{3} \mathrm{Cr}_{1}$ & -349.75 & -353.55 & -0.42 \\
$\mathrm{Ni}_{3} \mathrm{Mn}_{1}$ & -349.44 & -353.30 & -0.47 \\
$\mathrm{Ni}_{3} \mathrm{Fe}_{1}$ & -335.65 & -339.40 & -0.37 \\
$\mathrm{Ni}_{3} \mathrm{Co}_{1}$ & -309.08 & -312.82 & -0.35 \\
$\mathrm{Ni}_{1}$ bare & -283.84 & -287.67 & -0.45 \\
$\mathrm{Ni}_{3} \mathrm{Cu}$ & -258.57 & -262.44 & -0.49 \\
$\mathrm{Ni}_{3} \mathrm{Zn}_{1}$ & -230.78 & -234.80 & -0.64 \\
\hline
\end{tabular}

Table A4. Ground state energies of bare and with $\mathrm{OH}$ at (111) facet $(1 / 16 \mathrm{ML})$ supercell $2 \times 2 \times 1$ and calculated OHBE (all energies are in $\mathrm{eVs}$ ).

\begin{tabular}{cccc}
\hline Material & Bare (111) Facet & Surface with OH & OHBE/eV \\
\hline $\mathrm{Ni}_{3} \mathrm{Cr}_{1}$ & -496.02 & -506.77 & -0.35 \\
$\mathrm{Ni}_{3} \mathrm{Mn}_{1}$ & -494.24 & -504.68 & -0.04 \\
$\mathrm{Ni}_{3} \mathrm{Co}_{1}$ & -447.09 & -458.05 & -0.57 \\
$\mathrm{Ni}$ bare & -414.05 & -424.99 & -0.54 \\
$\mathrm{Ni}_{3} \mathrm{Cu}_{1}$ & -380.83 & -391.58 & -0.34 \\
\hline
\end{tabular}

Table A5. Ground state energies of bare and with $\mathrm{OH}$ at (200) facet (1/8 ML) supercell $2 \times 2 \times 1$ and calculated OHBE (all energies are in $\mathrm{eVs}$ ).

\begin{tabular}{cccc}
\hline Material & Bare (200) Facet & Surface with $\mathbf{O H}$ & OHBE/eV \\
\hline $\mathrm{Ni}_{3} \mathrm{Cr}_{1}$ & -251.46 & -263.04 & -1.18 \\
$\mathrm{Ni}_{3} \mathrm{Mn}_{1}$ & -251.86 & -263.06 & -0.81 \\
$\mathrm{Ni}_{3} \mathrm{Fe}_{1}$ & -241.93 & -252.45 & -0.11 \\
$\mathrm{Ni}$ bare & -203.61 & -214.76 & -0.75 \\
\hline
\end{tabular}

Table A6. Ground state energies of bare and with $\mathrm{OH}$ at (220) facet $(1 / 8 \mathrm{ML})$ supercell $2 \times 2 \times 1$ and calculated OHBE (all energies are in $\mathrm{eVs}$ ).

\begin{tabular}{cccc}
\hline Material & Bare (220) Facet & Surface with OH & OHBE/eV \\
\hline $\mathrm{Ni}_{3} \mathrm{Cr}_{1}$ & -349.75 & -360.01 & 0.14 \\
$\mathrm{Ni}_{3} \mathrm{Mn}_{1}$ & -349.44 & -360.01 & -0.17 \\
$\mathrm{Ni}_{3} \mathrm{Fe}_{1}$ & -335.65 & -345.11 & 0.93 \\
$\mathrm{Ni}$ bare & -283.84 & -294.73 & -0.49 \\
\hline
\end{tabular}




\section{References}

1. Varcoe, J.R.; Atanassov, P.; Dekel, D.R.; Herring, A.M.; Hickner, M.A.; Kohl, P.A.; Kucernak, A.R.; Mustain, W.E.; Nijmeijer, K.; Scott, K.; et al. Anion-exchange membranes in electrochemical energy systems. Energy Environ. Sci. 2014, 7, 3135-3191. [CrossRef]

2. Gottesfeld, S.; Dekel, D.R.; Page, M.; Bae, C.; Yan, Y.; Zelenay, P.; Kim, Y.S. Anion exchange membrane fuel cells: Current status and remaining challenges. J. Power Sources 2018, 375, 170-184. [CrossRef]

3. Dekel, D.R.; Amar, M.; Willdorf, S.; Kosa, M.; Dhara, S.; Diesendruck, C.E. Effect of water on the stability of quaternary ammonium groups for anion exchange membrane fuel cell applications. Chem. Mater. 2017, 29, 4425-4431. [CrossRef]

4. Yim, S.-D.; Chung, H.T.; Chlistunoff, J.; Kim, D.-S.; Fujimoto, C.; Yang, T.-H.; Kim, Y.S. A Microelectrode study of interfacial reactions at the platinum-alkaline polymer interface. J. Electrochem. Soc. 2015, 162, F499-F506. [CrossRef]

5. Dekel, D.R.; Willdorf, S.; Ash, U.; Amar, M.; Pusara, S.; Dhara, S.; Srebnik, S.; Diesendruck, C.E. The critical relation between chemical stability of cations and water in anion exchange membrane fuel cells environment. J. Power Sources 2018, 375, 351-360. [CrossRef]

6. Ziv, N.; Dekel, D.R. A practical method for measuring the true hydroxide conductivity of anion exchange membranes. Electrochem. Commun. 2018, 88, 109-113. [CrossRef]

7. Omasta, T.J.; Wang, L.; Peng, X.; Lewis, C.A.; Varcoe, J.R.; Mustain, W.E. Importance of balancing membrane and electrode water in anion exchange membrane fuel cells. J. Power Sources 2018, 375, 205-213. [CrossRef]

8. Diesendruck, C.E.; Dekel, D.R. Water-A key parameter in the stability of anion exchange membrane fuel cells. Curr. Opin. Electrochem. 2018, 9, 173-178. [CrossRef]

9. Zheng, Y.; Ash, U.; Pandey, R.P.; Ozioko, A.G.; Ponce-González, J.; Handl, M.; Weissbach, T.; Varcoe, J.R.; Holdcroft, S.; Liberatore, M.W.; et al. Water uptake study of anion exchange membranes. Macromolecules 2018, 51, 3264-3278. [CrossRef]

10. Wang, L.; Bellini, M.; Miller, H.A.; Varcoe, J.R. A high conductivity ultrathin anion-exchange membrane with $500+\mathrm{h}$ alkali stability for use in alkaline membrane fuel cells that can achieve $2 \mathrm{~W} \mathrm{~cm}^{-2}$ at $80^{\circ} \mathrm{C}$. J. Mater. Chem. A 2018, 6, 15404-15412. [CrossRef]

11. Pusara, S.; Srebnik, S.; Dekel, D.R. Molecular simulation of quaternary ammonium solutions at low hydration levels. J. Phys. Chem. C 2018, 122, 11204-11213. [CrossRef]

12. Willdorf-Cohen, S.; Mondal, A.; Dekel, D.R.; Diesendruck, C.E. Chemical stability of poly(phenylene oxide)-based ionomers in anion exchange-membrane fuel cell environment. J. Mater. Chem. A 2018. [CrossRef]

13. Krewer, U.; Weinzierl, C.; Ziv, N.; Dekel, D.R. Impact of carbonation processes in anion exchange membrane fuel cells. Electrochim. Acta 2018, 263, 433-446. [CrossRef]

14. Ziv, N.; Mustain, W.E.; Dekel, D.R. The Effect of ambient carbon dioxide on anion-exchange membrane fuel cells. ChemSusChem 2018, 11, 1136-1150. [CrossRef] [PubMed]

15. Ziv, N.; Mondal, A.N.; Weissbach, T.; Holdcroft, S.; Dekel, R.D. Effect of $\mathrm{CO}_{2}$ on the properties of anion exchange membranes for fuel cell applications. Macromolecules 2018, submitted.

16. Gerhardt, M.R.; Pant, L.M.; Weber, A.Z. Modeling water management and carbon dioxide contamination effects in anion-exchange membrane fuel cells. ECS Trans. 2018, 86, 15-24. [CrossRef]

17. Rasin, I.G.; Page, M.; Dekel, D.R.; Brandon, S. A model based analysis of alkaline membrane fuel cells. ECS Trans. 2017, 80, 1051-1057. [CrossRef]

18. Dekel, D.R.; Rasin, I.G.; Page, M.; Brandon, S. Steady state and transient simulation of anion exchange membrane fuel cells. J. Power Sources 2018, 375, 191-204. [CrossRef]

19. Dario, R.; Dekel, D.R.; Rasin, I.G.; Brandon, S. Predicting performance stability in anion exchange membrane fuel cells. ACS Energy Lett. 2018. submitted.

20. Lefèvre, M.; Proietti, E.; Jaouen, F.; Dodelet, J.-P. Iron-based catalysts with improved oxygen reduction activity in polymer electrolyte fuel cells. Science 2009, 324, 71-74. [CrossRef] [PubMed]

21. Bashyam, R.; Zelenay, P. A class of non-precious metal composite catalysts for fuel cells. Nature 2006, 443, 63-66. [CrossRef] [PubMed]

22. Davydova, E.S.; Mukerjee, S.; Jaouen, F.; Dekel, D.R. Electrocatalysts for hydrogen oxidation reaction in alkaline electrolytes. ACS Catal. 2018, 8, 6665-6690. [CrossRef] 
23. Wang, L.; Magliocca, E.; Cunningham, E.L.; Mustain, W.E.; Poynton, S.D.; Escudero-Cid, R.; Nasef, M.M.; Ponce-González, J.; Bance-Souahli, R.; Slade, R.C.T.; et al. An optimised synthesis of high performance radiation-grafted anion-exchange membranes. Green Chem. 2017, 19, 831-843. [CrossRef]

24. Dekel, D.R. Review of cell performance in anion exchange membrane fuel cells. J. Power Sources 2018, 375, 158-169. [CrossRef]

25. Miller, H.A.; Vizza, F.; Marelli, M.; Zadick, A.; Dubau, L.; Chatenet, M.; Geiger, S.; Cherevko, S.; Doan, H.; Pavlicek, R.K.; et al. Highly active nanostructured palladium-ceria electrocatalysts for the hydrogen oxidation reaction in alkaline medium. Nano Energy 2017, 33, 293-305. [CrossRef]

26. Alesker, M.; Page, M.; Shviro, M.; Paska, Y.; Gershinsky, G.; Dekel, D.R.; Zitoun, D. Palladium/nickel bifunctional electrocatalyst for hydrogen oxidation reaction in alkaline membrane fuel cell. J. Power Sources 2016, 304, 332-339. [CrossRef]

27. Omasta, T.J.; Peng, X.; Miller, H.A.; Vizza, F.; Wang, L.; Varcoe, J.R.; Dekel, D.R.; Mustain, W.E. Beyond 1.0 W $\mathrm{cm}^{-2}$ performance without platinum: The beginning of a new era in anion exchange membrane fuel cells. J. Electrochem. Soc. 2018, 165, J3039-J3044. [CrossRef]

28. Zhuang, Z.; Giles, S.A.; Zheng, J.; Jenness, G.R.; Caratzoulas, S.; Vlachos, D.G.; Yan, Y. Nickel supported on nitrogen-doped carbon nanotubes as hydrogen oxidation reaction catalyst in alkaline electrolyte. Nat. Commun. 2016, 7, 1-8. [CrossRef] [PubMed]

29. Sheng, W.; Bivens, A.P.; Myint, M.; Zhuang, Z.; Forest, R.V.; Fang, Q.; Chen, J.G.; Yan, Y. Non-precious metal electrocatalysts with high activity for hydrogen oxidation reaction in alkaline electrolytes. Energy Environ. Sci. 2014, 7, 1719-1724. [CrossRef]

30. Kristinsdóttir, L.; Skúlason, E. A systematic DFT study of hydrogen diffusion on transition metal surfaces. Surf. Sci. 2012, 606, 1400-1404. [CrossRef]

31. Lu, S.F.; Pan, J.; Huang, A.B.; Zhuang, L.; Lu, J.T. Alkaline polymer electrolyte fuel cells completely free from noble metal catalysts. Proc. Natl. Acad. Sci. USA 2008, 105, 20611-20614. [CrossRef]

32. Mauer, A.E.; Kirk, D.W.; Thorpe, S.J. The role of iron in the prevention of nickel electrode deactivation in alkaline electrolysis. Electrochim. Acta 2007, 52, 3505-3509. [CrossRef]

33. Bates, M.K.; Jia, Q.; Ramaswamy, N.; Allen, R.J.; Mukerjee, S. Composite Ni/NiO-Cr $\mathrm{O}_{3}$ catalyst for alkaline hydrogen evolution reaction. J. Phys. Chem. C 2015, 119, 5467-5477. [CrossRef] [PubMed]

34. Kabir, S.A.; Lemire, K.; Artyushkova, K.; Roy, A.; Odgaard, M.; Schlueter, D.; Oshchepkov, A.; Bonnefont, A.; Savinova, E.; Sabarirajan, D.C.; et al. Platinum group metal-free NiMo hydrogen oxidation catalysts: High performance and durability in alkaline exchange membrane fuel cells. J. Mater. Chem. A 2017, 5, 24433-24443. [CrossRef]

35. Oshchepkov, A.; Simonov, P.; Cherstiouk, O.; Nazmutdinov, R.; Glukhov, D.; Zaikovskii, V.; Kardash, T.; Kvon, R.; Bonnefont, A.; Simonov, A.; et al. On the effect of $\mathrm{Cu}$ on the Activity of carbon supported Ni nanoparticles for hydrogen electrode reactions in alkaline medium. Top. Catal. 2015, 58, 1-12. [CrossRef]

36. Tang, M.H.; Hahn, C.; Klobuchar, A.J.; Ng, J.W.D.; Wellendorff, J.; Bligaard, T.; Jaramillo, T.F. Nickel-silver alloy electrocatalysts for hydrogen evolution and oxidation in an alkaline electrolyte. Phys. Chem. Chem. Phys. 2014, 16, 19250-19257. [CrossRef] [PubMed]

37. Cherstiouk, O.V.; Simonov, P.A.; Oshchepkov, A.G.; Zaikovskii, V.I.; Kardash, T.Y.; Bonnefont, A.; Parmon, V.N.; Savinova, E.R. Electrocatalysis of the hydrogen oxidation reaction on carbon-supported bimetallic NiCu particles prepared by an improved wet chemical synthesis. J. Electroanal. Chem. 2016, 783, 146-151. [CrossRef]

38. Davydova, E.S.; Dekel, D.R. Ni-Based Hydrogen Oxidation reaction electrocatalysts for alkaline anion-exchange membrane fuel cells: Systematic study on the doping effect. In Meeting Abstracts; The Electrochemical Society: Pennington, NJ, USA, 2017; p. 1635.

39. Sheng, W.; Zhuang, Z.; Gao, M.; Zheng, J.; Chen, J.G.; Yan, Y. Correlating hydrogen oxidation and evolution activity on platinum at different $\mathrm{pH}$ with measured hydrogen binding energy. Nat. Commun. 2015, 6, 1-6. [CrossRef] [PubMed]

40. Zheng, J.; Zhuang, Z.; Xu, B.; Yan, Y. Correlating hydrogen oxidation/evolution reaction activity with the minority weak hydrogen-binding sites on Ir/C catalysts. ACS Catal. 2015, 5, 4449-4455. [CrossRef]

41. Nørskov, J.K.; Bligaard, T.; Logadottir, A.; Kitchin, J.R.; Chen, J.G.; Pandelov, S.; Stimming, U. Trends in the exchange current for hydrogen evolution. J. Electrochem. Soc. 2005, 152, J23-J26. [CrossRef] 
42. Erdey-Gruz, T.; Volmer, M. ZurTheorie der WasserstoffÜberspannung. Z. Phys. Chem. Abteil. Chem. Thermodyn. Kinet. Electrochem. Eig. 1930, 150, 203-206.

43. Heyrovsky, J. A theory of overpotential. Recl. Trav. Chim. Pays-Bas 1927, 46, 582-585. [CrossRef]

44. Marković, N.M.; Sarraf, S.T.; Gasteiger, H.A.; Ross, P.N. Hydrogen electrochemistry on platinum low-index single-crystal surfaces in alkaline solution. J. Chem. Soc. Faraday Trans. 1996, 92, 3719-3725. [CrossRef]

45. Sheng, W.; Gasteiger, H.A.; Shao-Horn, Y. Hydrogen oxidation and evolution reaction kinetics on platinum: Acid vs alkaline electrolytes. J. Electrochem. Soc. 2010, 157, B1529. [CrossRef]

46. Ross, P.N.; Stonehart, P. Correlations between electrochemical activity and heterogeneous catalysis for hydrogen dissociation on platinum. J. Res. Inst. Catal. Hokkaido Univ. 1974, 22, 22-41.

47. Bagotzky, V.S.; Osetrova, N.V. Investigations of hydrogen ionization on platinum with the help of micro-electrodes. J. Electroanal. Chem. 1973, 43, 233-249. [CrossRef]

48. Stonehart, P.; Kohlmayr, G. Effect of poisons on kinetic parameters for platinum electrocatalyst sites. Electrochim. Acta 1972, 17, 369-382. [CrossRef]

49. Zheng, J.; Sheng, W.; Zhuang, Z.; Xu, B.; Yan, Y. Universal dependence of hydrogen oxidation and evolution reaction activity of platinum-group metals on $\mathrm{pH}$ and hydrogen binding energy. Sci. Adv. 2016, 2, e1501602. [CrossRef] [PubMed]

50. Durst, J.; Siebel, A.; Simon, C.; Hasche, F.; Herranz, J.; Gasteiger, H.A. New insights into the electrochemical hydrogen oxidation and evolution reaction mechanism. Energy Environ. Sci. 2014, 7, 2255-2260. [CrossRef]

51. Floner, D.; Lamy, C.; Leger, J.M. Electrocatalytic oxidation of hydrogen on polycrystal and single-crystal nickel electrodes. Surf. Sci. 1990, 234, 87-97. [CrossRef]

52. Oshchepkov, A.G.; Bonnefont, A.; Saveleva, V.A.; Papaefthimiou, V.; Zafeiratos, S.; Pronkin, S.N.; Parmon, V.N.; Savinova, E.R. Exploring the influence of the nickel oxide species on the kinetics of hydrogen electrode reactions in alkaline media. Top. Catal. 2016, 59, 1319-1331. [CrossRef]

53. Schmidt, T.J.; Ross, P.N.; Markovic, N.M. Temperature dependent surface electrochemistry on Pt single crystals in alkaline electrolytes: Part 2. The hydrogen evolution/oxidation reaction. J. Electroanal. Chem. 2002, 524, 252-260. [CrossRef]

54. Mahoney, E.G.; Sheng, W.; Yan, Y.; Chen, J.G. Platinum-modified gold electrocatalysts for the hydrogen oxidation reaction in alkaline electrolytes. ChemElectroChem 2014, 1, 2058-2063. [CrossRef]

55. Alia, S.M.; Pivovar, B.S.; Yan, Y. Platinum coated copper nanowires with high activity for hydrogen oxidation reaction in base. J. Am. Chem. Soc. 2013, 135, 13473-13478. [CrossRef] [PubMed]

56. Elbert, K.; Hu, J.; Ma, Z.; Zhang, Y.; Chen, G.; An, W.; Liu, P.; Isaacs, H.S.; Adzic, R.R.; Wang, J.X. Elucidating hydrogen oxidation/evolution kinetics in base and acid by enhanced activities at the optimized pt shell thickness on the ru core. ACS Catal. 2015, 5, 6764-6772. [CrossRef]

57. Balzarotti, A.; De Crescenzi, M.; Motta, N.; Patella, F.; Sgarlata, A. Valence charge fluctuations in $\mathrm{YBa}_{2} \mathrm{Cu}_{3} \mathrm{O}_{7-\delta}$ from core-level spectroscopies. Phys. Rev. B 1988, 38, 6461-6469. [CrossRef]

58. Mansour, A.N. Copper $\mathrm{Mg} K_{\alpha}$ XPS spectra from the physical electronics model 5400 spectrometer. Surf. Sci. Spectra 1994, 3, 202-210. [CrossRef]

59. Jolley, J.G.; Geesey, G.G.; Hankins, M.R.; Wright, R.B.; Wichlacz, P.L. Auger electron and X-ray photoelectron spectroscopic study of the biocorrosion of copper by alginic acid polysaccharide. Appl. Surf. Sci. 1989, 37, 469-480. [CrossRef]

60. Hussain, Z.; Salim, M.A.; Khan, M.A.; Khawaja, E.E. X-ray photoelectron and auger spectroscopy study of copper-sodium-germanate glasses. J. Non-Cryst. Solids 1989, 110, 44-52. [CrossRef]

61. Shabanova, I.N.; Trapeznikov, V.A. A study of the electronic structure of $\mathrm{Fe}_{3} \mathrm{C}, \mathrm{Fe}_{3} \mathrm{Al}$ and $\mathrm{Fe}_{3} \mathrm{Si}$ by $\mathrm{X}$-ray photoelectron spectroscopy. J. Electron Spectrosc. Relat. Phenom. 1975, 6, 297-307. [CrossRef]

62. Tan, B.J.; Klabunde, K.J.; Sherwood, P.M.A. X-ray photoelectron spectroscopy studies of solvated metal atom dispersed catalysts. Monometallic iron and bimetallic iron-cobalt particles on alumina. Chem. Mater. 1990, 2 , 186-191. [CrossRef]

63. Oshchepkov, A.G.; Bonnefont, A.; Parmon, V.N.; Savinova, E.R. On the effect of temperature and surface oxidation on the kinetics of hydrogen electrode reactions on nickel in alkaline media. Electrochim. Acta 2018, 269, 111-118. [CrossRef]

64. Miller, H.A.; Lavacchi, A.; Vizza, F.; Marelli, M.; Di Benedetto, F.; D’Acapito, F.; Paska, Y.; Page, M.; Dekel, D.R. A Pd/C- $\mathrm{CeO}_{2}$ Anode Catalyst for high-performance platinum-free anion exchange membrane fuel cells. Angew. Chem. Int. Ed. Engl. 2016, 55, 6004-6007. [CrossRef] [PubMed] 
65. Li, J.; Ghoshal, S.; Bates, M.K.; Miller, T.E.; Davies, V.; Stavitski, E.; Attenkofer, K.; Mukerjee, S.; Ma, Z.-F.; Jia, Q. Experimental proof of the bifunctional mechanism for the hydrogen oxidation in alkaline media. Angew. Chem. Int. Ed. 2017, 56, 15594-15598. [CrossRef] [PubMed]

66. Strmcnik, D.; Uchimura, M.; Wang, C.; Subbaraman, R.; Danilovic, N.; van der Vliet, D.; Paulikas, A.P.; Stamenkovic, V.R.; Markovic, N.M. Improving the hydrogen oxidation reaction rate by promotion of hydroxyl adsorption. Nat. Chem. 2013, 5, 300-306. [CrossRef] [PubMed]

67. Ramaswamy, N.; Ghoshal, S.; Bates, M.K.; Jia, Q.; Li, J.; Mukerjee, S. Hydrogen oxidation reaction in alkaline media: Relationship between electrocatalysis and electrochemical double-layer structure. Nano Energy 2017, 41, 765-771. [CrossRef]

68. Koper, M.T.M.; Van Santen, R.A. Interaction of H, O and $\mathrm{OH}$ with metal surfaces. J. Electroanal. Chem. 1999, 472, 126-136. [CrossRef]

69. Medford, A.J.; Vojvodic, A.; Hummelshøj, J.S.; Voss, J.; Abild-Pedersen, F.; Studt, F.; Bligaard, T.; Nilsson, A.; Nørskov, J.K. From the Sabatier principle to a predictive theory of transition-metal heterogeneous catalysis. J. Catal. 2015, 328, 36-42. [CrossRef]

70. Striebel, K.A.; McLarnon, F.R.; Cairns, E.J. Oxygen reduction on Pt in aqueous $\mathrm{K}_{2} \mathrm{CO}_{3}$ and KOH. J. Electrochem. Soc. 1990, 137, 3351-3359. [CrossRef]

71. Wang, Y.; Wang, G.; Li, G.; Huang, B.; Pan, J.; Liu, Q.; Han, J.; Xiao, L.; Lu, J.; Zhuang, L. Pt-Ru catalyzed hydrogen oxidation in alkaline media: Oxophilic effect or electronic effect? Energy Environ. Sci. 2015, 8, 177-181. [CrossRef]

72. Ohyama, J.; Sato, T.; Yamamoto, Y.; Arai, S.; Satsuma, A. Size specifically high activity of Ru nanoparticles for hydrogen oxidation reaction in alkaline electrolyte. J. Am. Chem. Soc. 2013, 135, 8016-8021. [CrossRef] [PubMed]

73. Roy, A.; Talarposhti, M.R.; Normile, S.J.; Zenyuk, I.V.; De Andrade, V.; Artyushkova, K.; Serov, A.; Atanassov, P. Nickel-copper supported on a carbon black hydrogen oxidation catalyst integrated into an anion-exchange membrane fuel cell. Sustain. Energy Fuels 2018. [CrossRef]

74. Kresse, G.; Hafner, J. Ab initio molecular dynamics for open-shell transition metals. Phys. Rev. B 1993, 48, 13115-13118. [CrossRef]

75. Kresse, G.; Furthmüller, J. Efficiency of ab-initio total energy calculations for metals and semiconductors using a plane-wave basis set. Comput. Mater. Sci. 1996, 6, 15-50. [CrossRef]

76. Perdew, J.P.; Burke, K.; Ernzerhof, M. Generalized gradient approximation made simple. Phys. Rev. Lett. 1996, 77, 3865-3868. [CrossRef] [PubMed]

77. Stamenkovic, V.R.; Fowler, B.; Mun, B.S.; Wang, G.; Ross, P.N.; Lucas, C.A.; Markovic, N.M. Improved oxygen reduction activity on $\mathrm{Pt}_{3} \mathrm{Ni}(111)$ via Increased surface site availability. Science 2007, 315, $493-497$. [CrossRef] [PubMed]

78. Studt, F.; Abild-Pedersen, F.; Bligaard, T.; Sorensen, R.Z.; Christensen, C.H.; Norskov, J.K. Identification of non-precious metal alloy catalysts for selective hydrogenation of acetylene. Science 2008, 320, 1320-1322. [CrossRef] [PubMed]

79. Nikolla, E.; Schwank, J.; Linic, S. Comparative study of the kinetics of methane steam reforming on supported $\mathrm{Ni}$ and $\mathrm{Sn} / \mathrm{Ni}$ alloy catalysts: The impact of the formation of Ni alloy on chemistry. J. Catal. 2009, 263, 220-227. [CrossRef]

80. Sitthisa, S.; An, W.; Resasco, D.E. Selective conversion of furfural to methylfuran over silica-supported NiFe bimetallic catalysts. J. Catal. 2011, 284, 90-101. [CrossRef]

81. Kresse, G. From ultrasoft pseudopotentials to the projector augmented-wave method. Phys. Rev. B 1999, 59, 1758-1775. [CrossRef]

82. Blöchl, P.E. Projector augmented-wave method. Phys. Rev. B 1994, 50, 17953-17979. [CrossRef]

83. Ziegel, E.; Press, W.; Flannery, B.; Teukolsky, S.; Vetterling, W. Numerical recipes: The art of scientific computing. Technometrics 1987. [CrossRef] 
84. Patterson, A.L. The Scherrer formula for X-ray particle size determination. Phys. Rev. 1939, 56, 978-982. [CrossRef]

85. Maurya, S.; Dumont, J.; Narvaez Villarrubia, C.; Matanovic, I.; Li, D.; Kim, Y.S.; Noh, S.; Han, J.; Bae, C.; Miller, H.A.; et al. Surface adsorption affects the performance of alkaline anion-exchange membrane fuel cells. ACS Catal. 2018, 8, 9429-9439. [CrossRef] 